\title{
Neoplastic diseases of commercially important marine bivalves
}

\author{
Bruce J. Barber ${ }^{\mathrm{a}}$ \\ Eckerd College, Galbraith Marine Science Laboratory, 4200 54th Ave. South, St. Petersburg, FL 33711, USA
}

\begin{abstract}
This review summarizes the current state of knowledge regarding the two primary proliferative diseases of commercially important marine bivalves. Disseminated neoplasia is characterized by the presence of large (2-4 times the diameter of normal hemocytes), anaplastic, circulating cells that have a hyperchromatic and often pleomorphic nucleus containing one or more prominent nucleoli. Prevalence exceeding $90 \%$ has been reported; the disease is progressive and can result in significant mortality of affected populations. Softshell clams, Mya arenaria, and mussels, Mytilus trossulus, from the east and west coasts of North America, respectively, and cockles, Cerastoderma edule, from Ireland, appear to be especially susceptible. Disseminated neoplasia can be transmitted to uninfected individuals, indicating an infectious (perhaps viral) etiology, the expression of which may be aggravated by environmental degradation. Gonadal neoplasia consists of small, basophilic, undifferentiated cells that originate as small foci in gonadal follicles where they proliferate and eventually invade surrounding tissues. This disease primarily affects $M$. arenaria in Maine (USA) and Mercenaria spp. in Florida (USA) at prevalences up to 50\%. Most affected individuals are female. Limited field studies to date indicate that the disease progresses slowly and mortality rates are low. The major impact is most likely a reduction in reproductive effort. The finding that prevalence of gonadal neoplasia is higher in hybrid Mercenaria spp. suggests a genetic etiology. Precise determination of the etiology and other aspects of both diseases will benefit greatly from future advances in cellular and molecular biological techniques.
\end{abstract}

Key words: Neoplasia / Bivalves / Molluscs

\section{Overview}

The first comprehensive review of proliferative disorders (tumors) in mollusks presented criteria for distinguishing between neoplasia, hyperplasia, and response to injury or infection (Pauley 1969). Sindermann (1990) broadly defined a tumor as "any swelling or abnormal mass of tissue resulting from 1) non-neoplastic, controlled cell proliferation (hyperplasia); 2) a non-neoplastic increase in cell size (hypertrophy); or 3) an uncontrolled cell proliferation (neoplasia)". Further, he made the distinction between benign (nonfatal) and malignant (fatal) tumors (based on Sparks 1985) and recognized that examples of hemocytic sarcomas and germinomas meeting the criteria of malignancy do occur in marine bivalves.

The significant body of knowledge accumulated since 1990 has confirmed the presence of two predominant types of malignant neoplasia that occur rather widely in marine bivalves. The first of these consists of a proliferation of abnormal circulating cells of unknown origin, referred to in this review as "disseminated neoplasia". The second consists of a proliferation of undifferentiated germ cells, herein called "gonadal neoplasia". Both fit the criteria of malignant tumors, including atypical structure (often with pleomorphic, undifferentiated cells); rapid and invasive growth; an abundance of mitotic

\footnotetext{
${ }^{a}$ Corresponding author: barberbj@eckerd.edu
}

figures; metastasis; and progressive growth resulting in death of the host (Sparks 1985).

This paper will focus on these two types of malignant neoplasia because they affect several commercially important species worldwide, sometimes at epizootic levels, and have economic and potential ecological consequences. The intent here is not to provide an exhaustive review of the literature, but rather to provide a general overview of the major aspects of these proliferative diseases, their impacts on commercially important species, and to update and augment the most recent reviews (Peters 1988; Sindermann 1990; Elston et al. 1992; Peters et al. 1994). Particular attention will be given to the physiological impacts of neoplasms at cellular, whole animal, and population levels, as well as the etiology and progenitor cells of these diseases. Finally, as it becomes clear what we do know about these diseases, it will become increasingly clear what we do not know which will in turn provide direction for future research efforts.

\section{Disseminated neoplasia}

\subsection{Diagnosis}

Farley (1969a) first reported a "probable neoplastic disease of the hematopoietic system" in oysters, Crassostrea virginica and $C$. gigas. Morphologically similar cases have 


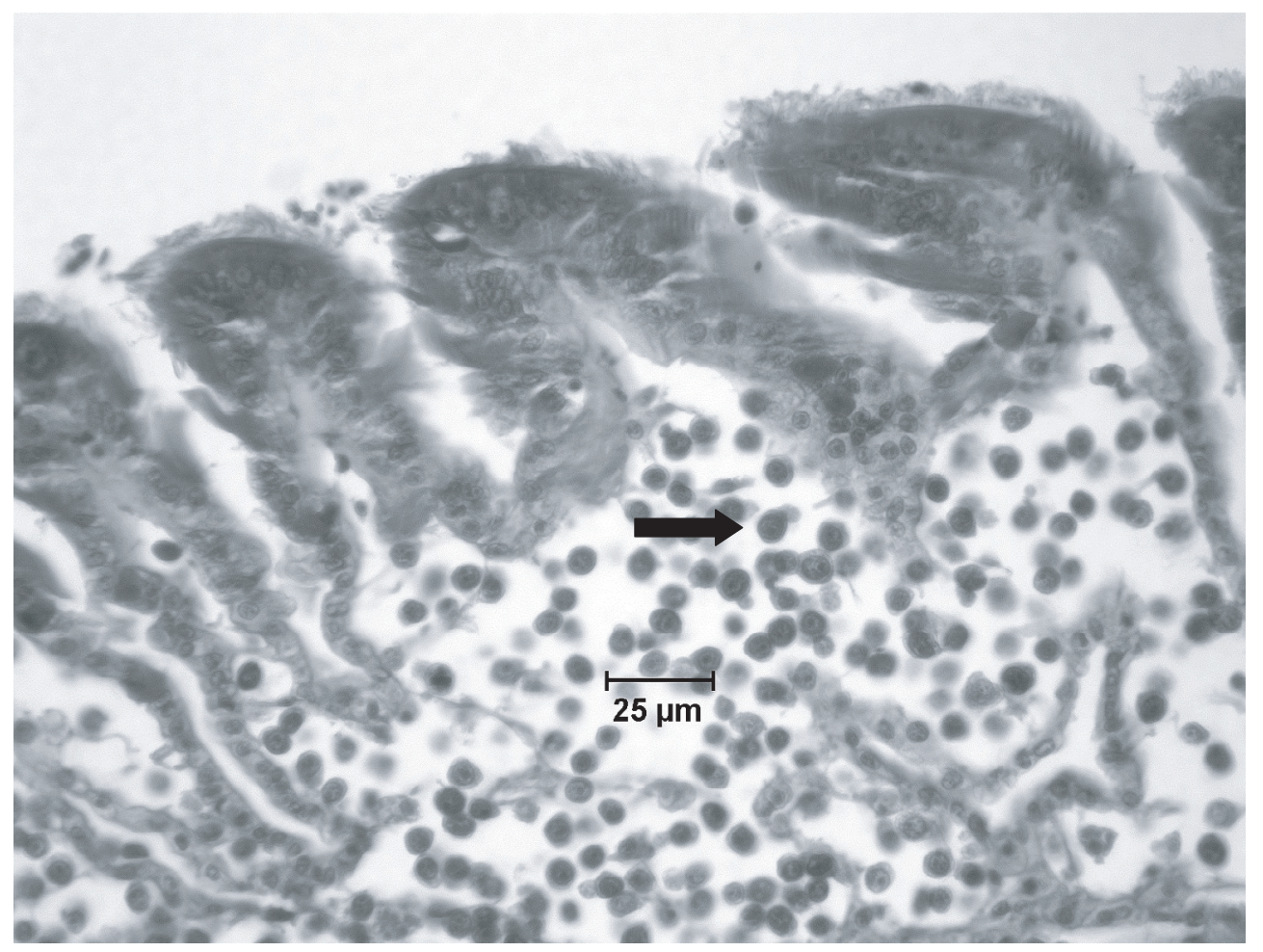

Fig. 1. Histopathological section of Mya arenaria gill tissue containing large, anaplastic circulating cells diagnostic for disseminated neoplasia. Note large nucleus to cytoplasm ratio (arrow).

since been reported for several species of bivalves, and have been given a number of names, including, "hematopoietic neoplasia" (Yevich and Barszcz 1977), "disseminated sarcoma" (Peters 1988), or simply "hemic neoplasia" (Elston et al. 1988a; McGladdery et al. 2001), all of which imply hemocytic origin. Elston et al. (1992), however, argue for the more general moniker, "disseminated neoplasia", since a progenitor cell type has not been firmly established for any of these apparently similar conditions. This review will use the more conservative term "disseminated neoplasia", based on the lack of evidence regarding the origin of proliferating cells and the possibility that there may in fact be more than one tissue of origin for this condition.

Regardless of host species, disseminated neoplasia displays several common characteristics (Figs. 1 and 2), the most notable of which is the presence of large, anaplastic cells in the connective tissue, blood vessels, and sinuses of the visceral mass, muscle, and mantle tissue (see Peters 1988; Elston et al. 1992). These cells are hypertrophied (2-4 times the diameter of normal hemocytes) and have a hyperchromatic and often pleomorphic nucleus containing one or more prominent nucleoli. As a result, there is a high nucleus to cytoplasm ratio, and mitotic figures are common; indeed cellular division in neoplastic cells occurs at a much greater rate than in normal cells (Mix 1975). These cells also have many ultrastructural features in common with malignant vertebrate cells, including swollen mitochondria and altered Golgi complexes (Mix et al. 1979; Auffret and Poder 1986). In wet mount preparations, neoplastic cells exhibit a lack of adhesion, spreading, and phagocytic behavior (see Brown et al. 1977; Peters 1988; Elston et al. 1992).

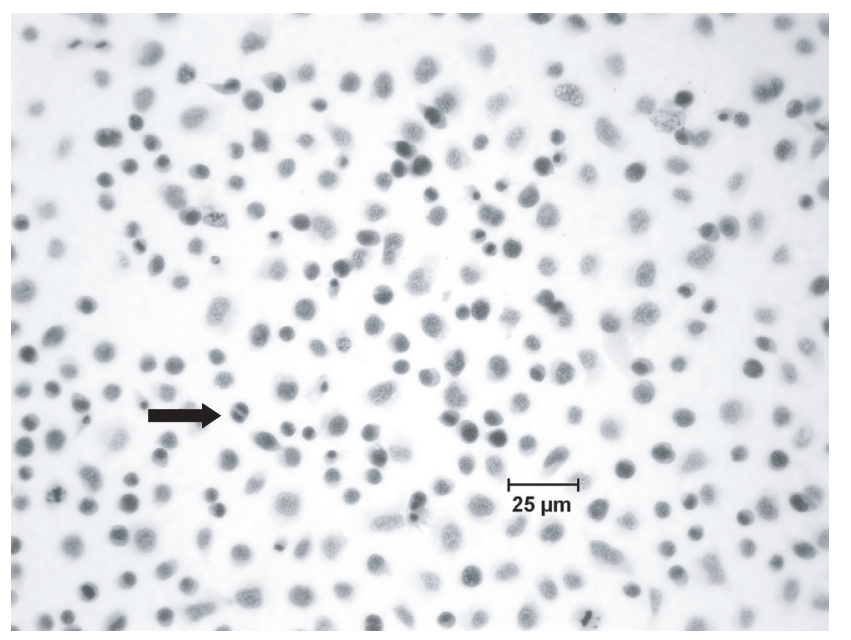

Fig. 2. Hemocytological preparation from Mya arenaria with advanced case of disseminated neoplasia. Note presence of pleomorphic nuclei containing one or more prominent nucleoli and actively dividing cells (arrow).

Relative amounts of DNA in neoplastic cells may vary among affected species. For example, Elston et al. (1990) and Moore et al. (1991) found that hemolymph from affected mussels, Mytilus edulis ${ }^{1}$, contained cells having $3.8 \times$ haploid

\footnotetext{
1 The genus Mytilus is now recognized as consisting of four species: M. edulis, M. trossulus, M. galloprovincialis, and M. californianus (Koehn 1991). References to M. edulis from the west coast of North America are thus most likely M. trossulus, and from this point forward will be referred to as such.
} 
(tetraploid) and $4.9 \mathrm{x}$ haploid (pentaploid) DNA content and concluded that the two forms represent different pathogenetic processes rather than sequential stages of a single process. Disseminated neoplasia in M. edulis from Britain also consisted of two cell types, having 3.8-4.3 (type A) or 6.8-7.7 (type B) times the amount of DNA in normal hemocytes; these, however, were thought to be a single cell line (Lowe and Moore 1978). Examination of normal and neoplastic cells of softshell clams, Mya arenaria, revealed that neoplastic cells had 1.25 to 2.05 times more DNA than normal cells and a chromosome number ranging from 44-80 compared to 26-39 for normal cells (Reno et al. 1994).

\subsection{Detection}

Disseminated neoplasia is generally not recognized by gross examination of specimens (Farley 1969b; Brown et al. 1977). Possible physiological effects of the disease (tissue emaciation, pale digestive gland, and mantle recession) are too general to be diagnostic. Early reports of disseminated neoplasia were made on the basis of standard histopathological examination of fixed tissue (Farley 1969a, 1969b; Yevich and Barszcz 1976). The primary advantage of this method is that it provides a frame of reference for comparing normal and abnormal conditions. In the case of disseminated neoplasia, abnormal circulating cells can be viewed within the context of surrounding tissues. Histopathology also provides information on which disease progression (severity, intensity) can be assessed relative to the various tissues. For example, Mix (1983) assigned stages of disease severity for mussels based on histological examination as follows: Stage 1 cases are characterized by the presence of a small number of neoplastic cells or small foci of cells; in Stage 2 cases, neoplastic cells have begun to infiltrate connective tissues; in Stage 3 cases, neoplastic cells have infiltrated throughout connective tissues and are present in hemolymph sinuses; and in Stage 4 cases, neoplastic cells are present in high numbers throughout the body. Primary disadvantages of histopathology are the relatively high cost per sample and lengthy processing time.

Since disseminated neoplasia involves circulating cells, this disease also lends itself to direct examination of hemolymph and its cellular contents. This approach, termed "histocytology" by Farley et al. (1986), and later "hemocytology" by Peters (1988) and Elston et al. (1992), involves removing a sample of hemolymph $(0.1-0.5 \mathrm{ml})$ from the bivalve (preferably from the posterior adductor muscle) with a hypodermic needle, diluting it appropriately with filtered seawater, and placing the sample on a glass slide. Advanced cases of the disease are immediately noticeable in the blood sample itself, which is more opaque (due to the greater number of larger cells) than normal hemolymph (Moore et al. 1991). Since neoplastic cells have lost their phagocytic capability, slides first need to be coated with poly-L-lysine to promote adhesion (Cooper et al. 1982b; Farley et al. 1986). After cells have settled and attached to the slide they can then be viewed live with phase contrast optics or fixed and stained with brightfield optics (Brown et al. 1977; Cooper et al. 1982a). If cells are fixed, stained, and mounted with a coverslip, a permanent record is obtained (Farley et al. 1986; Elston et al. 1988a). The primary advantage of this approach is the relative speed at which a large number of animals can be examined (e.g., Farley et al. 1986; Farley et al. 1991). A second advantage is that drawing a blood sample is non-destructive, such that individuals can be repeatedly sampled without affecting survival (Brown et al. 1977; Cooper et al. 1982b). This approach has allowed investigators to track disease progression and rates of mortality (see Sect. 2.3).

Hemocytology can also be used to ascertain disease severity, since the ratio of circulating neoplastic cells to normal hemocytes increases as the disease progresses. For example, Cooper et al. (1982a) established five levels of severity based on the number of neoplastic cells perml of softshell clam (Mya arenaria) hemolymph: Level 1 clams had fewer than $10^{4}$ neoplastic cells per ml; Level 2 clams had $2 \times 10^{4}$ to $10^{5}$ neoplastic cells per ml; Level 3 clams had between $1.1 \times 10^{5}$ and $10^{6}$ neoplastic cells per ml; Level 4 clams had $1.01 \times 10^{6}$ to $10^{7}$ neoplastic cells per ml; and Level 5 clams had more than $10^{7}$ neoplastic cells per ml of hemolymph. Similarly, Farley et al. (1986) used the ratios of neoplastic to normal hemocytes in $M$. arenaria hemolymph samples to assign stage of disease severity: Stages 1 and 2 represented early stages of the disease, having $0.01-0.9 \%$ neoplastic cells; Stage 3 cases were intermediate and had 1-49\% neoplastic cells; and Stages 4 and 5 represented advanced cases, having 50-100\% neoplastic cells. Brousseau and Baglivo (1991a, 1991b) divided clams, M. arenaria, into three groups: non-neoplastic (no abnormal cells detected); low-severity neoplastic (1-50\% visible cells were neoplastic); or highseverity neoplastic (51-100\% of observed cells were neoplastic). Rather than classify positive cases of disseminated neoplasia by category, Barber (1990) used actual cell counts (percentage of total cells that were neoplastic) to determine disease intensity in M. arenaria.

There is some disagreement as to which approach, histopathology or hemocytology, is more capable of accurately detecting disseminated neoplasia. Cooper et al. (1982b) found that cytology revealed only $66-71 \%$ of Level 1 (early) cases while Farley et al. (1986) found that hemocytology was more sensitive at detecting early cases of the disease than histology, which was only reliable for identification of advanced cases. The relative accuracy of these two approaches is most likely a function of the relative amount of tissue that is processed and examined. With histopathology, only one tissue section $(6 \mu \mathrm{m})$ is normally processed and examined per individual. Since this section represents only a small portion of the entire animal, early cases consisting of small foci or a few, isolated neoplastic cells, might well go undetected. Similarly, with hemocytology only a relatively small proportion of the entire blood volume of an individual is processed and examined. Early cases of disseminated neoplasia have few circulating cells to begin with, making it more likely that these cases will not be detected.

The sensitivity and accuracy of the hemocytological method was improved by Smolowitz and Reinisch (1986), who developed an indirect peroxidase staining of hemocyte preparations that had been treated with monoclonal antibodies specific for neoplastic cells. Neoplastic cells stained a bright red color, making them easy to distinguish from normal cells. As 
a result, a greater number of cells can be examined within a reasonable period of time, increasing the likelihood that rare neoplastic cells are seen, thus improving the sensitivity (ability to detect early cases). The specific nature of the staining procedure removes ambiguity as to whether a particular cell is neoplastic or normal, thus improving accuracy (likelihood that the diagnosis of an early case is correct). This technique was used to determine prevalence and stage of development of disseminated neoplasia in $M$. arenaria collected from two sites in Massachusetts, USA (Leavitt et al. 1990). A minimum of 10000 cells from each clam were counted and assigned to one of three categories. Stage 1 cases had fewer than $15 \%$ neoplastic cells; Stage 2 clams had $16-70 \%$ neoplastic cells; and Stage 3 cases had greater than $71 \%$ abnormal cells.

Neoplastic cells contain more DNA than normal cells and thus are detectable in a hemolymph sample using flow cytometry. Advantages to this approach include the ability to process a large number of cells rather quickly and objectively, since the flow cytometer counts and sorts cells based on DNA content. Using this technique, Moore et al. (1991) established that disseminated neoplasia in Mytilus trossulus consists of two distinct types of neoplastic cells having differing DNA contents, information that was not apparent using either histopathology or hemocytology.

\subsection{Epizootiology}

Disseminated neoplasia has been reported for 15 species of marine bivalves throughout the world (see Peters 1988; Elston et al. 1992). Similarities and differences in neoplastic cell characteristics and pathologic manifestations of this disease among species are reviewed by Elston et al. (1992) and will not be covered here. This review will focus on those species which are commercially important and for which occurrence of disseminated neoplasia is epizootic as determined by intense sampling of feral populations.

\subsubsection{Crassostrea virginica}

The eastern oyster, Crassostrea virginica, is native to the east coast of North America and supports an important fishery and aquaculture industry. Prevalence of disseminated neoplasia in this species is relatively low, as reported by Frierman and Andrews (1976), who found an overall prevalence of $<0.08 \%$ in over 14 years (1959-1973) of monitoring oysters in Chesapeake Bay; in two genetically selected lines, however, prevalence was found to be $8.4 \%$ (Frierman and Andrews 1976). In Delaware Bay, prevalence of disseminated neoplasia has also been historically low $(<0.01 \%)$, but in 1991, a relatively high prevalence $(2.3 \%$ ) occurred in the 1990 year class; a peak prevalence of $5 \%$ occurred in June in conjunction with maximum gonadal development (Ford et al. 1997).

\subsubsection{Mya arenaria}

Incidence of disseminated neoplasia in softshell clams, Mya arenaria, has been widely documented along its native range of Labrador to South Carolina on the east coast of North America. Farley et al. $(1986,1991)$ reported an epizootic that occurred in Chesapeake Bay in 1983 in a previously diseasefree population; prevalence increased seasonally to summer maxima ranging from $40 \%$ to $90 \%$ followed by associated mortality. For a population of clams in the Shrewsbury River, New Jersey (Barber 1990) found that prevalence and intensity of disseminated neoplasia varied seasonally and were inversely related, with intensity maxima occurring in October and April and prevalence maxima occurring in December and May. Brousseau (1987) sampled 3 sites in Long Island Sound from 1983 to 1985 and found overall prevalences of $6.1 \%$, $12.9 \%$, and $12.7 \%$ with peak prevalences of $45 \%, 59 \%$, and $60 \%$, respectively, that occurred in late fall. When this data was evaluated with respect to sex and age, it was found that disease prevalence was significantly lower for female clams than male clams, but there was no clear pattern of prevalence that could be related to clam age (Brousseau and Baglivo 1994); at one site the proportion of neoplastic clams was significantly lower for clams 2-3 yr. old while at another site the incidence of disease was significantly lower in the $>3$ yr. old age class. Similarly, Leavitt et al. (1990) compared prevalence of disseminated neoplasia at 2 sites in Massachusetts from 1986 to 1987 and found that monthly prevalence ranged from $<10 \%$ to over $50 \%$, with highest prevalence occurring in the fall. The authors also noted that prevalence was greater in 3-4 year old clams than either younger $(<2$ y) or older $(>4$ y) individuals. In a later study, prevalence of disseminated neoplasia in $M$. arenaria was found to be strongly season-dependent, with the probability of disease being greatest in summer; this relationship was enhanced in the larger size classes (Weinberg et al. 1997). In New Brunswick and Nova Scotia (Bay of Fundy) Canada, prevalence ranged from $3.1 \%$ to $31.3 \%$ at 6 of 22 sites sampled between 1985 and 1987 (Morrison et al. 1993). More recently, however, mortalities of clams in Prince Edward Island were linked to a high prevalence (up to 95\%) of disseminated neoplasia (McGladdery et al. 2001).

\subsubsection{Mytilus spp.}

Mussels of the genus Mytilus are distributed circumboreally in the Northern Hemisphere, and disseminated neoplasia occurs in both European and North American populations. Two of three sub-populations of mussels (most likely M. trossulus) in Yaquina Bay, Oregon, sampled between 1976 and 1981 had neoplasms at prevalences of $0-20 \%$ with a mean prevalence of $9.8 \%$ (Mix 1983). Prevalence was significantly related to time of year, being greatest from January to March, but intensity was not related to season. In British Columbia, three mussel populations (most likely M. trossulus) were sampled in 1980 and 1981 and found to have an overall prevalence of disseminated neoplasia of $12.7 \%$; sample prevalence ranged from 0-29.2\% (Cosson-Mannevy et al. 1984).

Prevalences of disseminated neoplasia in mussel (M. edulis) populations in northern Europe and on the east coast of North America are generally lower (usually less than 4\%) than those of M. trossulus on the west coast of North America (Bower et al. 1994). Mussel populations were sampled at 21 sites in the United Kingdom between 1978 and 
1979; mussels from six sites had a prevalence of neoplasia up to $4.3 \%$ (Green and Alderman 1983). At three sites in Denmark, annual prevalence in 1983 and 1984 averaged 0.2 to $0.8 \%$; peak prevalence at two sites (2.0 to $2.3 \%$ ) was seasonally related (Rasmussen 1986).

\subsubsection{Ostrea edulis}

The plate oyster, Ostrea edulis, is native to European waters. Reports of disseminated neoplasia in O. edulis populations first came from populations in Spain and Yugoslavia (Alderman et al. 1977). Subsequently, Balouet et al. (1986) undertook a six year (1975-1981) disease survey of oysters along the coast of France. They found 166 positive cases of disseminated neoplasia in 28976 oysters (prevalence $=0.57 \%$ ), with a significant increase in occurrence in the summer in older (>30 mo.) oysters.

\subsubsection{Cerastoderma edule}

The cockle, Cerastoderma edule, is also distributed throughout Europe. Poder and Auffret (1986) sampled three sites in Brittany, France between 1982 and 1984 and found disseminated neoplasia in every sample at one site at prevalences ranging from 2 to 46\%. In Ireland, Twomey (1994) and Twomey and Mulcahy (1988a) examined several populations of $C$. edule, including one site which was sampled monthly from 1983 to 1985 . Mean monthly prevalence at this site (Cuskinny, Cork Harbour) was $41 \%$ (range of $13 \%$ to $72 \%$ ) and was significantly related to season, with greatest prevalence occurring in June and November. In addition, it was found that the age class distribution of cockles with disseminated neoplasia was significantly different than that of normal cockles, with individuals in the $2-5$ year old classes having a greater prevalence than younger or older individuals (Twomey and Mulcahy 1988a). High mortalities of cockles observed in northwest Spain in 1997 were associated with a higher prevalence (up to $84 \%$ ) of disseminated neoplasia compared to control areas (4\% prevalence) not experiencing mortality (Villalba et al. 2001).

\subsubsection{Synthesis}

Disseminated neoplasia appears most consistently at epizootic levels in populations of clams, Mya arenaria, cockles, Cerastoderma edule, and mussels Mytilus trossulus, and less so for populations of oysters Crassostrea virginica and Ostrea edulis, and mussels, Mytilus edulis. For the populations of M. arenaria and $C$. edule examined, there is generally a consistently low prevalence, which can suddenly and dramatically increase, causing substantial mortality (and economic losses) within a population (Farley et al. 1986; Farley et al. 1991; McGladdery et al. 2001; Villalba et al. 2001). For $M$. arenaria and $C$. edule, prevalence can fluctuate seasonally due to increases in prevalence and intensity leading to mortality, which acts to subsequently reduce prevalence (Farley et al. 1986; Brousseau 1987; Twomey and Mulcahy 1988a;
Barber 1990; Leavitt et al. 1990; Farley et al. 1991). Additionally, disseminated neoplasia is capable of affecting population structure by selectively killing particular age classes (Twomey and Mulcahy 1988a; Leavitt et al. 1990; Potts 1993; Brousseau and Baglivo 1994). This effect, however, is not consistent between years and locations, given differences in growth rate and recruitment success of various year classes. In some instances, disease prevalence has been correlated with seasonal reproductive activity or sex of individuals (Potts 1993; Brousseau and Baglivo 1994; Ford et al. 1997).

Just as interesting as where disseminated neoplasia occurs is where it does not occur. For example, reports of disseminated neoplasia are virtually absent for the Pacific oyster, Crassostrea gigas, in spite of its now global geographic distribution. To date, only one case has been reported, in spite of thousands of individuals being examined in both Europe and Asia (Farley 1969a; Balouet et al. 1986). Also conspicuously lacking are reports of disseminated neoplasia in M. edulis from the east coast of North America (Bower et al. 1994). Thus it appears that $C$. gigas and M. edulis are genetically resistant to disseminated neoplasia, in spite of the fact that closely related species, C. virginica and M. trossulus, respectively, are highly susceptible.

\subsection{Physiological effects}

\subsubsection{Sublethal effects}

Early stages of disseminated neoplasia, when viewed histologically, are characterized by foci of neoplastic cells or a few isolated abnormal cells throughout the circulatory system. As the neoplastic cells multiply, the tumors become more diffuse as cells become widely distributed throughout the tissues. Concurrent with the increase in the number of abnormal neoplastic cells, the number of normal hemocytes, especially hyaline hemocytes, decreases (see Peters 1988; Elston et al. 1992). Tissue pathology includes collagenous fibrosis; displacement, compression, and necrosis of normal gill, gonad, and connective tissues; arrest of gametogenesis and gonadal atrophy; widespread degeneration and necrosis of tissues (Farley 1969a; Brown et al. 1977; Lowe and Moore 1978; Poder and Auffret 1986; Peters 1988). Disseminated neoplasia generally progresses, and once beyond a certain point, results in death of the host organism (Cooper et al. 1982a; Farley et al. 1986; Elston et al. 1988a; Barber 1990).

Undoubtedly this pathology leads to the tissue emaciation, pale, watery tissues, and mantle recession exhibited by individuals with advanced cases of the disease (Farley 1969a; Farley 1969b; Brown et al. 1977). These are general indications that affected individuals are experiencing nutritional stress, the result of either a reduction in energy intake or assimilation, or an extra metabolic burden imposed by the rapidly multiplying neoplastic cells. For example, Leavitt et al. (1990) found that Mya arenaria with advanced cases of disseminated neoplasia (Stages 2 or 3 ) had significantly lower tissue dry weight and condition index than clams without the disease. A lower tissue weight and condition index can be the result of impaired gametogenesis. Accordingly, the gonadal follicles of $M$. arenaria 
with Stages 2 and 3 (advanced) cases of disseminated neoplasia were significantly smaller (23\% and $32 \%$, respectively) than in healthy clams (Potts 1993). Similarly, Ford et al. (1997) reported that the gonad index of oysters, Crassostrea virginica, having disseminated neoplasia was generally lower than that of non-affected oysters. These studies indicate that as the disease progresses, the reproductive potential of affected individuals is negatively impacted. It follows that if disease prevalence is high enough, the sustainability of the population could be jeopardized.

\subsubsection{Lethal effects}

Several studies have demonstrated the progressive nature of disseminated neoplasia and quantified rates of progression and mortality associated with it. Cooper et al. (1982a) repeatedly examined softshell clams, Mya arenaria, (using hemocytology) in laboratory experiments of 4-6 months and separated them into categories based on disease severity. They found that clams with neoplasms had significantly $(P \leq 0.05)$ greater mortality than healthy clams and that mortality, which ranged from $40 \%$ to $100 \%$, was correlated with disease severity. In clams that did not die over the course of the experiment, the disease either increased in severity (43\%), remained the same $(40 \%)$, or regressed $(16 \%)$.

A similar experiment was performed with mussels, Mytilus trossulus by Elston et al. (1988a) who maintained 40 individuals collected from Puget Sound in the laboratory and repeatedly examined them (using hemocytology) over a 128 day period. Ten of these $(25 \%)$ remained disease free throughout the experimental period; $20(50 \%)$ developed the disease which resulted in the death of 12 individuals; and, 8(20\%) were in a state of remission at the end of the experiment.

Barber (1990) improved on these studies by repeatedly examining 27 diseased and 27 non-diseased softshell clams, Mya arenaria, which had been individually marked and placed under a predator exclusion cage at an intertidal site in Delaware Bay. All clams were sampled non-destructively (hemocytology) every two weeks and then replaced over a period of three months. Disease intensity was determined quantitatively as the proportion of cells that were neoplastic based on counts of cells in up to 16 microscope fields (200X). Within the group initially diagnosed as having the disease, 93\% (25/27) died over the course of the experiment compared to $48 \%(13 / 27)$ of those clams initially diagnosed as being disease-free. Within the group that started the experiment having disseminated neoplasia, disease intensity increased in $85 \%$ (23/27), until death occurred. Four clams (15\%), however, initially diagnosed as having neoplasia lost the disease, and four (15\%) initially diagnosed as being neoplasia-free, developed the disease. In addition, there was a significant $(P \leq 0.01)$ inverse correlation between disease intensity and time to death.

In larger field experiments, over 2200 adult Mya arenaria were collected, tagged, sampled (hemocytology), and replanted near Milford, Connecticut in four separate six month studies (Brousseau and Baglivo 1991a, 1991b). After six months, clams were recovered and re-examined for the presence and severity of disseminated neoplasia. As in previous studies, mortality was significantly greater $(p \leq 0.001)$ for clams having neoplasia than for clams without neoplasia. Mortality of clams originally diagnosed as having disseminated neoplasia ranged from $48 \%$ to $78 \%$ compared to $3 \%$ to $21 \%$ for clams initially determined to be disease-free. Disease progression and remission occurred at all stages of the disease.

\subsubsection{Synthesis}

Several conclusions can be drawn from these studies. In the vast majority of cases, once disseminated neoplasia is initiated, it will progress and result in the death of the host. In a few cases, however, regression of the disease will occur, but only in animals having early (low intensity) cases. Once the disease reaches a certain intensity (>23\% neoplastic cells), however, progression to death is almost certain (Barber 1990). Disease remission, at least in the case of mussels, was accomplished by entrapment of neoplastic cells by an extracellular matrix secreted by normal hemocytes (Elston et al. 1988a). Obviously new cases of the disease occur in completely healthy clams, but it is also possible that in some of the studies just reported, very early cases of pre-existing conditions were simply not detected.

So what actually causes the death of bivalves with advanced cases of disseminated neoplasia? As noted above, as disseminated neoplasia progresses, normal hemocytes are replaced by abnormal (neoplastic) cells, which exhibit little spreading activity. One of the primary roles of hemocytes in bivalves is defense, which can involve phagocytosis, encapsulation, hemocytosis, or nacrezation (Sindermann 1990). Thus the loss of hemocytes and their associated defense functions would leave the host immuno-compromised. In fact, neoplastic cells of mussels, Mytilus trossulus, failed to phagocytose yeast cells in vitro and mussels with advanced cases of disseminated neoplasia had a reduced ability to clear bacteria in vivo (Kent et al. 1989). Similarly, clams, Mya arenaria, with disseminated neoplasia exhibited a reduced ability to accumulate radiopharmaceutical Tc-99-m-sulfur colloid particles (Potts 1993). Thus individuals affected by disseminated neoplasia could die as the result of a secondary infection, although there is little evidence for this. In addition to the loss of phagocytic ability, neoplastic cells also lose their ability to adhere (see Sect. 2.1), possibly as the result of an alteration of cell surface proteins. Miosky et al. (1989) developed an anti-neoplastic cell specific monoclonal antibody which bound to a large protein $(200 \mathrm{kDa})$ from neoplastic cells of $M$. arenaria, but not from normal hemocytes or tissue cells. A monoclonal antibody specific to normal hemocytes (designated MAB 2A4) reacted with a $130 \mathrm{kDa}$ protein on normal cells; as the disease progressed and the proportion of neoplastic cells increased, this $130 \mathrm{kDa}$ protein was lost, indicating that it may involved in regulating cell adhesion (White et al. 1993).

In addition to the loss of normal cellular defense mechanisms, there is evidence that humoral defenses may also be impaired by disseminated neoplasia. It was reported that clams, Mya arenaria, with disseminated neoplasia produced unique serum proteins that gradually replaced normal serum proteins as the disease progressed (Sunila and Dungan 1992). It was proposed that the proteins associated with disseminated neoplasia were cytotoxic or tumor-promoting and that these 
replaced the normal defense-related serum proteins of healthy clams. Further, it was shown that injection of normal hemocytes along with serum from diseased clams caused mortality in recipient clams even though it did not result in development of disseminated neoplasia (Sunila 1992).

Besides defense and tissue repair functions, bivalve hemocytes are also responsible for digestion, absorption and transport of nutrients within the animal. It is reasonable that once these functions become diminished as the proportion of neoplastic cells increases (and normal hemocytes decreases), the animal would slowly starve to death. This is potentially compounded by the metabolic activities of the neoplastic cells, which are rapidly dividing. Sunila (1991) examined the respiration rate of neoplastic cells in Mya arenaria, and found that the partial pressure of oxygen in the hemolymph of diseased clams was significantly lower than in control clams and was correlated with mitotic activity and cell density. In addition, oxygen content of hemolymph was inversely related to disease severity (\% of neoplastic cells), such that the hemolymph of clams with advanced cases of disseminated neoplasia was strongly hypoxic (Sunila 1991). Thus another possible way in which disseminated neoplasia causes death is due to hypoxia and the resultant loss of normal cellular functions.

\subsection{Ontogeny}

Although disseminated neoplasia is generally considered to be a sarcoma (neoplasia of mesoderm-derived tissue, including undifferentiated mesenchymal cells, hematopoietic stem cells, and dedifferentiated vesicular connective tissue cells), there is no definitive consensus regarding the cytogenesis of the disease (Peters 1988; Elston et al. 1992). Observations of mitotic activity in the primordial epithelium of the gonad and the proximity of neoplastic cells to this tissue led Farley (1969a) to hypothesize that the gonad may provide the tissue of origin for both normal and neoplastic hemocytes, as well as gametes. Further support for the gonad as the site of neoplastic cell origin was provided by Rasmussen (1986), who noted that neoplastic cells, like gametic follicles, appear to arise from small foci of cells associated with bundles of collagenous fibrils within the vesicular connective tissue. Although Ford et al. (1997) did not find any direct evidence for a gonadal origin of disseminated neoplasia, the close association between neoplasia prevalence and gametogenesis suggests a possible link. Most authors, however, favor a hemopoietic origin because of morphologic similarities between neoplastic cells and either granular or hyaline hemocytes and the consistent observation that neoplastic cells are first seen in the circulatory system (Farley 1969b; Yevich and Barszcz 1976, 1977; Mix 1983; Balouet et al. 1986; McGladdery et al. 2001). Confirmation of this, however, is limited by the general lack of knowledge regarding bivalve hematopoiesis (Balouet and Poder 1980; Elston et al. 1990).

Experimental evidence supports the observations that neoplastic cells are related to hemocytes and may originate from connective tissue. Mix (1975) injected oysters (Ostrea lurida) with tritiated thymidine and found that the percentage of labeled cells was considerably greater in oysters with disseminated neoplasia than control (healthy) oysters; in addition, labeled neoplastic cells were observed in the connective tissues underlying all major organs. An antibody produced from neoplastic cells of softshell clams, Mya arenaria, reacted positively with neoplastic cells, a small portion of normal hemocytes, and "connective tissue cells", suggesting that the connective tissue cells may be the cell of origin of both the normal hemocytes and the neoplastic cells (Smolowitz et al. 1989). Similarly, antibodies produced from hemolymph of diseased mussels, Mytilus trossulus, were found to react with both normal and neoplastic hemocytes, indicating the presence of common antigens (Noel et al. 1991; Moore and Elston 1993). This could indicate that normal hemocytes and neoplastic cells are ontogenetically related or simply (and more likely) that both cell types were contained in the initial innoculum. Finally, it should also be considered that the different manifestations of the disease in different host species may be reflective of varying cell types having various tissue origins.

\subsection{Etiology}

The factor or factors responsible for causing disseminated neoplasia have not been clearly defined. The fact that disseminated neoplasia can be transmitted allogeneically between individuals suggests that an infective agent may be involved. Disseminated neoplasia has been transmitted via injection of hemolymph (hemocytes) between individual cockles, Cerastoderma edule (Twomey and Mulcahy 1988b) mussels, Mytilus trossulus (Elston et al. 1988b; Kent et al. 1991), and clams, Mya arenaria (Weinberg et al. 1997). Manifestation of the disease in individuals into which neoplastic cells have been injected, however, could simply be the result of the proliferation of introduced cells (transplantation) rather than the transformation of host cells (true transmission). To address this issue, Elston et al. (1988b) inoculated disease-free mussels, $M$. trossulus, with either hemolymph (containing intact cells) or homogenized hemolymph (no intact cells) from animals with advanced cases of disseminated neoplasia, and found that both groups developed the disease. The fact that the group inoculated with whole cells developed the disease more rapidly than the group inoculated with the homogenate suggested that disease transplantation had occurred; initiation of the disease by the cell-free homogenate, however, demonstrated transmission (Elston et al. 1988b). In a similar study with clams, M. arenaria, McLaughlin (1994) demonstrated that disseminated neoplasia developed in healthy clams after injection with (whole) hemolymph from diseased clams but not after injection with cell-free ultrafiltrate $(0.22 \mu \mathrm{m})$. Disseminated neoplasia was also transmitted to healthy clams by the injection of ova from diseased clams (Sunila 1994). Further support for an infectious etiology is provided by the fact that the disease develops in healthy individuals between six and sixteen months of being placed in close proximity to infected individuals (Brown 1980; Elston et al. 1988b). Finally, sudden occurrences of high disease prevalence and mortality in previously unaffected populations also suggests the sudden introduction of an infectious pathogenic agent to a naïve population (Farley et al. 1986; McGladdery et al. 2001). The finding that disseminated neoplasia was not transmitted from Mytilus trossulus to Mya arenaria, Ostrea edulis, or Ostreola 
conchaphila suggests that any potential infective agent is species specific (Kent et al. 1991).

\subsubsection{Viral}

A retrovirus could readily produce the chromosomal aberrations associated with disseminated neoplasia in Mytilus trossulus (Elston et al. 1990; Moore et al. 1991). Visual evidence for viral involvement, however, is lacking. Electron micrographs revealed "virus-like particles" in the nuclei of neoplastic cells from Mytilus edulis (Rasmussen 1986), although Elston et al. (1992) interpreted these structures to be nuclear pores. Ultrastructural examination of neoplastic cells from M. trossulus (Mix et al. 1979; Elston et al. 1988b) and Cerastoderma edule (Auffret and Poder 1986), however, revealed no obvious pathogens of any type.

Nonetheless, experimental evidence exists for a viral involvement in disseminated neoplasia in soft-shell clams, Mya arenaria. Brown (1980) reported that only clams with neoplasms contained oncornavirus, as indicated by developed bands in sucrose density gradients and reverse transcriptase activity (essential for retroviral replication). A virus (similar to a B-type retrovirus) isolated from neoplastic clams initiated disseminated neoplasia when injected into healthy clams, and was then re-isolated (Oprandy et al. 1981). In a subsequent study, 5-bromodeoxyuridine was used to induce retroviral expression and disseminated neoplasia in healthy M. arenaria; isolated retroviral-like particles initiated disease development when injected into healthy clams (Oprandy and Chang 1983). Both these studies have been criticized, however, mostly due to a lack of repeatability by other investigators (Elston et al. 1992). More recently, House et al. (1998) re-examined this issue by injecting healthy clams with either whole neoplastic cells, unfiltered cell homogenate, filtered cell homogenate, or purified (sucrose gradient) filtered cell homogenate, and found that only clams injected with whole cells developed disseminated neoplasia. This does not completely rule out a retroviral etiology, however, if the virus is associated with cell membranes, which in this study were effectively removed by centrifugation, even in the unfiltered homogenate treatment. Further, reverse transcriptase has been detected in neoplastic cells but not normal cells, supporting potential viral involvement in the disease process (Medina et al. 1993; House et al. 1998). The precise source of the transcriptase activity, however, will have to be determined before a retrovirus can be confirmed as the etiological agent of disseminated neoplasia. A second potential viral agent (icosahedral, $100 \mathrm{~nm}$ ) was isolated from ova of $M$. arenaria with disseminated neoplasia; injection of ova (without neoplastic cells) into healthy clams induced disease development (Sunila 1994). The interesting ramification here is that the normal release of ova during spawning could thus serve to spread the disease in feral populations.

\subsubsection{Environmental contamination}

The lack of an obvious infectious agent and the finding of neoplasia in bivalves at environmentally contaminated sites led to the hypothesis that various pollutants might initiate the development of disseminated neoplasia. Yevich and Barszcz $(1976,1977)$ examined over 14000 clams, Mya arenaria, from various sites along the east and west coast of the United States and only detected hemic neoplasms in clams from a site in Maine contaminated with jet fuel. Results of a three year survey correlating prevalence of neoplasia with petroleum derived hydrocarbons in sediments and clam tissue revealed a consistently low prevalence of disseminated neoplasia at pristine sites, but a higher prevalence at oil-spill sites (Brown 1980). Another large field survey conducted in upper Chesapeake Bay demonstrated a significant correlation between prevalence of disseminated neoplasia in M. arenaria and tissue levels of chlordane (Farley et al. 1991). It should be noted, however, that the chemical analysis was conducted on clams collected independently from those examined for the presence of disseminated neoplasia. The high prevalence of disseminated neoplasia in clams from New Bedford Harbor, Massachusetts was associated with PCB contamination (Reinisch et al. 1984).

The site where Lowe and Moore (1978) found mussels, Mytilus edulis, having disseminated neoplasia was contaminated with several aromatic hydrocarbons some of which are known carcinogens. As part of the national Mussel Watch Project, over 8000 mussels (Mytilus sp.) were collected between 1986 to 1991 from 80 sites along both U.S. coasts, analyzed for levels of organic and inorganic contaminants, and examined histologically for the presence of neoplasia (Hillman 1993). It was found that the 18 sites where neoplasia occurred had significantly higher concentrations of PAH, chlordane, pesticides, and cadmium.

There is equally compelling evidence supporting the lack of correlation between disease prevalence and environmental contamination. Brown et al. (1977) examined clams, Mya arenaria, from 10 sites on the northeast coast of the United States and found no clear relationship between prevalence of disseminated neoplasia and hydrocarbon pollution. Similarly, there was a lack of correlation between prevalence of disseminated neoplasia and site pollution in and around Boston Harbor, Massachusetts (Smolowitz and Leavitt 1996). One of the largest surveys ever undertaken to assess the influence of pollution on shellfish health was conducted in France between 1975 and 1981, which encompasses the time before and after the Amoco Cadiz oil spill. Over 45000 oysters, Ostrea edulis, were examined histologically and although prevalence of disseminated neoplasia was low overall, there was no relation to oil pollution (Balouet et al. 1986). Cockles, Cerastoderma edule, from 19 locations around the coast of Ireland, were surveyed specifically to examine the relationship between prevalence of neoplasia and environmental quality; although disseminated neoplasia occurred consistently within Cork Harbor (an impacted site), it also occurred at several more pristine sites, including Bantry Bay, at a prevalence of 94\% (Twomey 1994). More recently, Krishnakumar et al. (1999) found no relationship between body burdens of environmental contaminants (including PAHs, PCBs and heavy metals) and the prevalence of disseminated neoplasia in mussels, Mytilus trossulus, at nine sites in Puget Sound, Washington; prevalence ranged from $0-30 \%$ in mussels from the non-impacted sites and $10-28 \%$ in mussels from the impacted sites. A review of the association of cancerous diseases in aquatic animals and 
environmental pollutants concluded that there was little evidence supporting a "pollution" etiology for neoplasia (Mix 1986). It was found that most studies were of insufficient size or scope to address the issue and others lacked reliable chemical data. Even valid studies revealing statistically significant correlations do not indicate a causal relationship between a particular contaminant and disease etiology.

The results of bioassay experiments add to our understanding of the role of chemical contaminants in promoting development of disseminated neoplasia. Brown (1980) exposed clams, Mya arenaria, without disseminated neoplasia to treatments of either no sediment, clean sediment, oil-contaminated sediment, or a 50:50 mixture of clean and oil-contaminated sediment under a head tank containing either no clams, nonneoplastic clams, or neoplastic clams, and examined one-third of each group after 1.5, 4, and 6 months for hydrocarbon accumulation and development of neoplasia. The fact that neoplasia did not appear in the clams exposed to oil under the head tanks containing no clams or non-neoplastic clams clearly indicated that oil alone did not cause disseminated neoplasia. Within the groups under the head tank containing neoplastic clams, the greatest increase in prevalence of disseminated neoplasia occurred in the no sediment and the 50:50 sediment treatments. This was interpreted as an indication that there was a viral etiological agent involved (given that the disease was transmitted from sick to healthy clams) and that the stress of exposure to contaminated sediment enhanced disease development in clams (Brown 1980). In a later study, clams having Stage 1 cases of disseminated neoplasia were placed into both polluted (New Bedford Harbor) and unpolluted (Little Buttermilk Bay) sediments; after four months, no difference in disease status (prevalence or intensity) between treatments was found (Leavitt et al. 1994). Krishnakumar et al. (1999) fed neoplasia-free mussels, Mytilus sp., a diet of microencapsulated PAHs or PCBs for 30 days, and although tissue concentrations of these chemicals increased up to 940 times compared to control mussels during that time, there was no significant difference in the prevalence of disseminated neoplasia between experimental and control groups. In a second experiment, mussels having a moderate prevalence of disseminated neoplasia $(20 \%)$ were also fed microencapsulated contaminants and although prevalence of neoplasia increased after 180 days, there was no significant difference between treatment and control groups (Krishnakumar et al. 1999). Thus the results of bioassay experiments do not support a contaminant etiology for disseminated neoplasia, but suggest that some pollutants may act to exacerbate pre-existing conditions caused by an infectious (viral) agent.

\subsubsection{Biotoxins}

Bivalves are noted for their ability to accumulate neurotoxins (produced by toxic microalgae) which are highly toxic to humans. In a thought-provoking review, Landsberg (1996) noted that the distribution of disseminated neoplasia, particularly for mussels, Mytilus spp., and softshell clams, Mya arenaria, on the northwest and northeast coasts of the United States, respectively, coincides both spatially and temporally with outbreaks of several species of toxic dinoflagellates. It was suggested that sublethal effects of these toxins on bivalves may include increased susceptibility to disseminated neoplasia, particularly viral agents (Landsberg 1996). Unfortunately, there is no experimental data to either support or refute this hypothesis as it relates to disseminated neoplasia.

\subsubsection{Other stressors}

Stressors besides chemical pollution have been suggested as potential factors promoting the onset and severity of disseminated neoplasia. Twomey and Mulcahy (1988a) found a higher prevalence of disseminated neoplasia in cockles, Cerastoderma edule, at sites within Cork Harbor compared to sites outside the harbor; analysis of heavy metal concentrations in tissues were similar for both areas. The authors noted, however, that the harbor was generally eutrophic due to a variety of waste sources and that this has led to the production of large algae blooms which may stress cockle populations. For oysters, Crassostrea virginica, Ford et al. (1997) noted that high prevalence of disseminated neoplasia was associated with unusually heavy oyster settlement on shells in mesh bags and that crowding itself was stressful. It is also possible that the high density of oysters promoted transmission of an infective agent. Balouet et al. (1986) found a statistically greater prevalence of disseminated neoplasia in Ostrea edulis in the summer, which coincided with maximal spawning activity and peak infestations of the parasitic copepod, Mytilicola refringens. It is presumed that stress of any kind would negatively impact host defense mechanisms. Unfortunately, none of these observations are supported by quantitative data.

\subsubsection{Genetic}

The fact that certain bivalve species are more prone to the development of disseminated neoplasia undoubtedly has a genetic basis. Within a species, however, there is little support for a genetic etiology for this disease. The only relevant data are provided by Frierman and Andrews (1976), who found an elevated prevalence of disseminated neoplasia in two laboratoryproduced strains of oysters, Crassostrea virginica $(31 / 369=$ $8.4 \%)$, compared to native (wild) oysters $(39 / 51000=0.08 \%)$ examined between 1964 and 1973. This finding suggests that the laboratory-produced oysters were either genetically predisposed to disease development or that inbreeding resulted in a loss of heterozygosity which resulted in an increased susceptibility to the disease. Either way, there is little cause for concern at this time, as the fisheries of species most greatly affected by disseminated neoplasia (e.g., Mya arenaria, Mytilus trossulus, and Cerastoderma edule) rely on natural seed production. Eventual commercial hatchery production of seed will undoubtedly be accompanied by selective breeding programs aimed at increasing disease resistance (Ford and Haskin 1987; Barber et al. 1998).

\subsubsection{Synthesis}

In summary, there is little if any relationship between prevalence of disseminated neoplasia and environmental 
carcinogens, biotoxins, or other forms of physiological stress. A potential genetic contribution is similarly lacking, especially in feral populations. There is support for an infectious etiology, but the exact nature of this agent is unclear, although viruses are a primary candidate. According to Farley (1994), four groups of viruses with oncogenic potential have been identified in marine invertebrates, but none have been clearly implicated in a neoplastic disease. The variation in occurrence of disseminated neoplasia between species, locations, and time of year suggest that there may not be one universal etiological agent, but rather a suite of agents (Cooper et al. 1982a; Kent et al. 1991; Twomey 1994). More intriguing and more likely, is the possibility that the activity of an infectious agent (and resulting disease development) may be modified by a stressor such as an environmental pollutant (Brown 1980; Twomey and Mulcahy 1988a, 1988b; Miosky et al. 1989). What appears to be an infectious process could result from an infectious agent, such as a virus, or a heritable change in the genome of neoplastic cells followed by natural transplantation (Farley 1994; McLaughlin 1994; Sunila 1994).

\section{Gonadal neoplasia}

\subsection{Diagnosis}

Gonadal neoplasms (germinomas, tumors) of marine bivalve mollusks are classified into three basic histotypes, with those of germ cell origin being the most common (Peters et al. 1994). They were first reported and described in quahogs, Mercenaria spp., by Yevich and Barry (1969) and Barry and Yevich (1972) and more recently by Hesselman et al. (1988). These neoplasms are characterized by the replacement of normal germinal epithelium with large, polyhedral cells containing vesicular nuclei and a clear pink cytoplasm. Many of the cells have marginated chromatin and a prominent acidophilic nucleoli (Fig. 3). Gonadal tumors in the softshell clam, Mya arenaria, are comprised of small, basophilic, undifferentiated (germ) cells that proliferate rather than mature (Fig. 4). The nuclei of these cells are often eccentric and the nucleolus is frequently difficult to distinguish in the abundantly clumped chromatin (Brown et al. 1977). In both species, neoplastic cells appear initially as small foci in one or more gonadal follicles, multiply to completely fill most or all follicles, and are capable of metastasis after invading interfollicular connective tissue, body wall, epibranchial chamber, and genital ducts (Hesselman et al. 1988; Gardner et al. 1991; Peters et al. 1994; Barber 1996; Barber et al. 2002). Mitotically active cells are seen, although not as commonly as in cases of disseminated neoplasia (Barry and Yevich 1972; Hesselman et al. 1988). Based on all these characteristics, gonadal neoplasms are considered malignant.

\subsection{Detection}

Unlike cases of disseminated neoplasia, gross signs of gonadal neoplasia, at least in more advanced cases involving softshell clams, Mya arenaria, may be detectable upon gross examination. If the visceral mass (containing the gonad) is shrunken, darkened, or has a blotchy or uneven appearance relative to other clams, the presence of gonadal neoplasia may be indicated. To test the predictability of this approach, 35 clams were collected from a site known to be epizootic for gonadal neoplasia and scored as either being diseased or normal based on gross appearance. Subsequent histological examination of these clams revealed that 15 clams had cases of neoplasia compared to the 19 that were predicted; six clams predicted to have the disease did not and three clams thought to be normal actually had the disease (Barber, unpublished). It is almost certain that early cases of gonadal neoplasia would be impossible to detect visually. In addition, overall condition and appearance of the gonad (visceral mass) will vary seasonally with food availability and gametogenic activity. Thus gross appearance is only a rough predictor of disease prevalence in $M$. arenaria. Cases of gonadal neoplasia involving quahogs, Mercenaria spp., have not been associated with any gross morphological anomalies (Yevich and Barry 1969; Hesselman et al. 1988).

Ultimately, detection of cases of gonadal neoplasia depends on histolopathological examination of tissues (Yevich and Barszcz 1976, 1977; Peters et al. 1994). Light or early cases may still go undetected if the tissue section examined does not happen to contain neoplastic cells. Obviously the probability of correctly diagnosing the presence of gonadal neoplasia (or any disease) increases with the severity of the disease. Three stages of severity were recognized for cases of gonadal neoplasia in Mya arenaria (Barber 1996; Barber et al. 2002). Stage 1 neoplasms consisted of undifferentiated germs cells partially or totally filling one or more (but less than half of the total) follicles; loss of gonadal architecture was rare. Stage 2 neoplasms were characterized by the presence of undifferentiated germ cells in over $50 \%$ of visible follicles; usually there was some loss of tissue architecture, but with no evidence of invasion or metastasis. In Stage 3 neoplasms, most to all follicles were involved, loss of tissue architecture was common, and either invasion or metastasis was evident. For Mercenaria spp., severity of the disease was categorized by the percentage of gonadal follicles that contained neoplastic cells: Stage 1 cases had $<10 \%$; Stage 2 cases had 10\%-75\%; Stage 3 cases had $>75 \%$; and Stage 4 cases typically had an involvement of $75 \%-100 \%$ of follicles with invasion into surrounding tissue (Bert et al. 1993).

The fact that neoplastic germ cells are not prevalent in the circulatory system eliminates hemocytology as a means of detecting gonadal neoplasia. Histopathology involves destructive sampling so that individuals cannot be repeatedly sampled. This severely reduces our ability to determine rates of disease progression and resultant mortalities.

\subsection{Epizootiology}

Gonadal neoplasms are rarely seen in Eastern oysters, Crassostrea virginica; ocean quahogs, Arctica islandica; bay scallops, Argopecten irradians; and blue mussels, Mytilus edulis (Farley 1976; Harshbarger et al. 1979; Gardner et al. 1991; Peters et al. 1994). Epizootics of germinomas, however, do occur in populations of quahogs, Mercenaria spp. (Yevich and Barry 1969; Barry and Yevich 1972; Hesselman et al. 1988; Bert et al. 1993; Eversole and Heffernan 1995) 


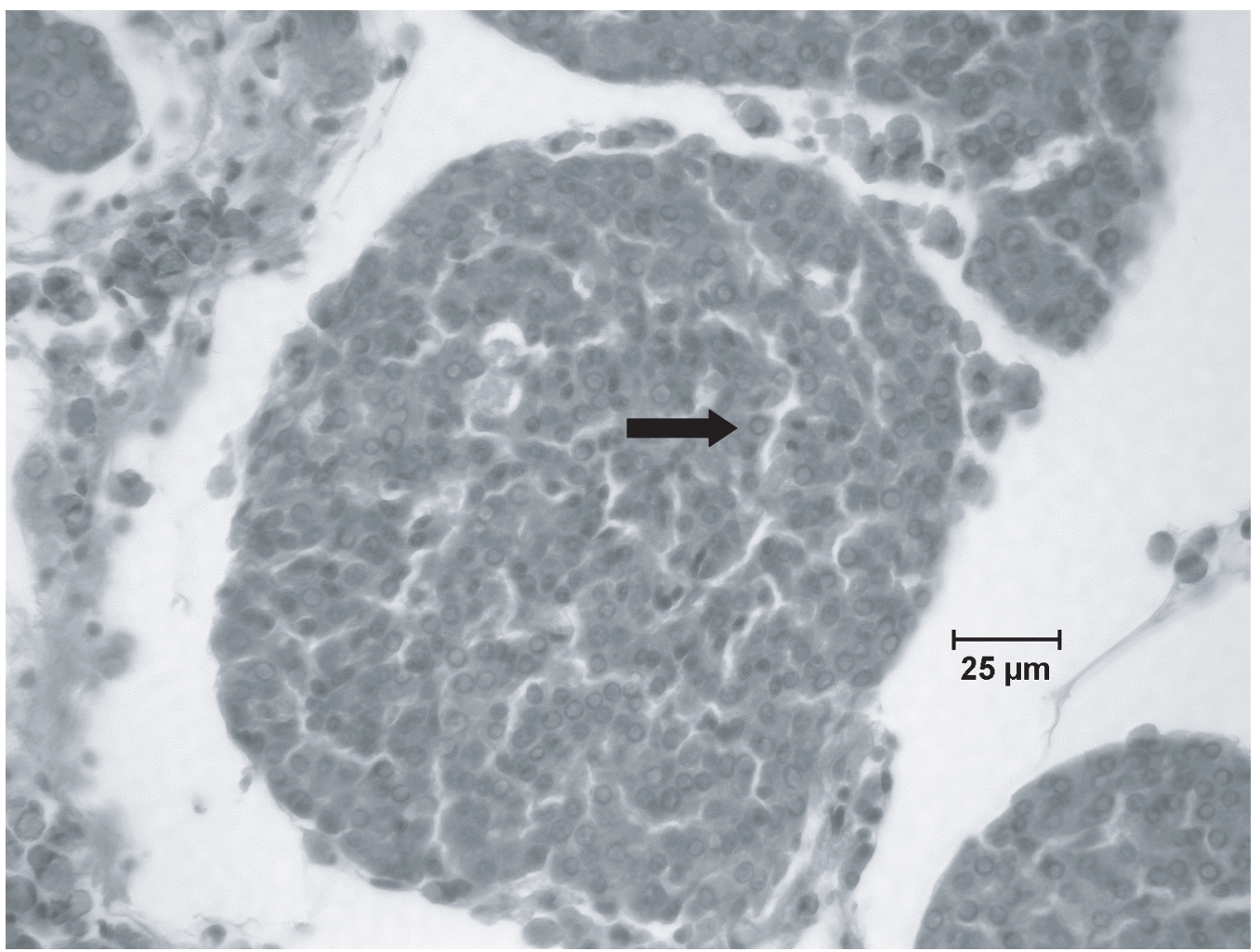

Fig. 3. Histopathological section of Mercenaria spp. gonadal tissue containing foci of small, basophilic, undifferentiated cells in follicles, diagnostic for gonadal neoplasia. Note marginated chromatin (arrow).

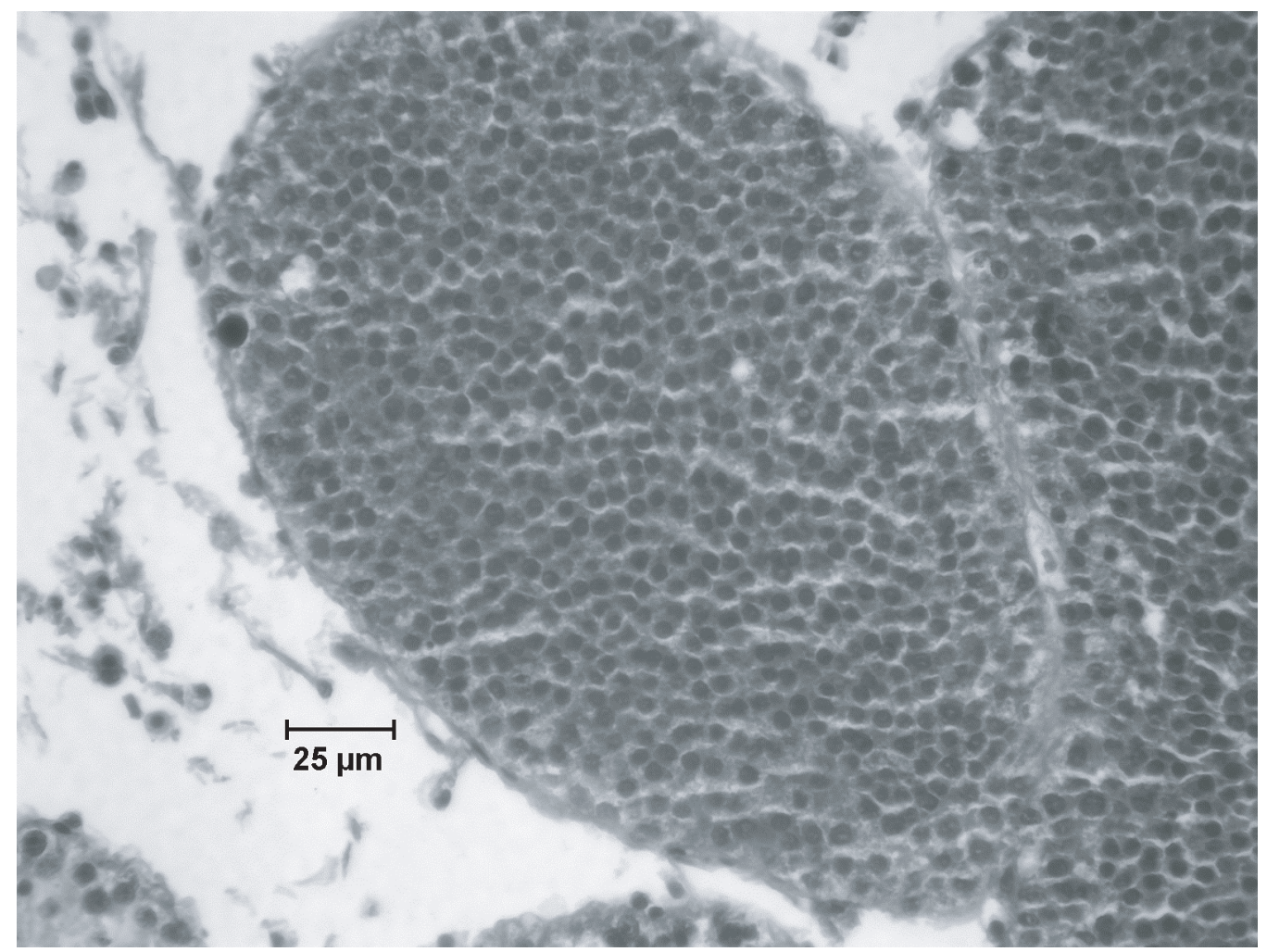

Fig. 4. Histopathological section of Mya arenaria with gonadal neoplasia. Neoplastic cells appear initially in gonadal follicles where they proliferate (inhibiting normal gametogenesis) and eventually invade surrounding tissues. 
and softshell clams, Mya arenaria (Barry and Yevich 1975; Gardner et al. 1991; Barber 1996; Barber et al. 2002).

\subsubsection{Mya arenaria}

To date, the majority of reported cases of gonadal neoplasms in M. arenaria have come from sites in Maine (USA), even though the species is distributed from Labrador to North Carolina along the east coast of North America. The condition was initially described in clams from Long Cove, Searsport, where 1 to $22 \%$ of individuals examined between 1971 and 1976 had neoplasms (Barry and Yevich 1975; Yevich and Barszcz 1976; Brown et al. 1977; Yevich and Barszcz 1977). Clams collected in 1980 from Rogue Bluffs (near Machiasport) and Dennys Bay (near Dennysville) had 3\% and $35 \%$ prevalences of gonadal neoplasms, respectively (Gardner et al. 1991). Five populations of clams from eastern Maine, sampled in 1993, had prevalences ranging from $6.7 \%$ to $42.9 \%$ (Barber and Davis 1994). In a follow-up study, monthly prevalences of clams collected from one of these sites (Whiting Bay), ranged from $10 \%$ to $26.7 \%$, with no obvious seasonal pattern of either prevalence or disease intensity; however, females had a significantly greater incidence of gonadal neoplasia than males (Barber 1995, 1996) ${ }^{2}$.

More recently, Barber et al. (2002) histologically examined 91 samples from 28 sites in Maine (USA) and New Brunswick, Nova Scotia, and Prince Edward Island (Canada). Gonadal neoplasia was detected at 10 of these locations at prevalences ranging from $3.3 \%$ to $50 \%$ and at all stages of development. Overall prevalence was $3.3 \%$ (116/3480). Of the 116 cases, 61 were classified as Stage 1, 47 as Stage 2, and eight as Stage 3. Prevalences exceeding $10 \%$ were found at only three locations: St. Andrews, New Brunswick, Mill Cove, Maine, and Whiting Bay, Maine. Advanced (Stage 3) cases were only found in Maine. Prevalence was not correlated with clam size, but neoplasia occurred more often in females than males. This work establishes the southern geographic distribution of gonadal neoplasia in $M$. arenaria as Penobscot Bay, Maine, and is supported by the fact that gonadal neoplasms have not been observed in M. arenaria from locations to the south of Maine (Massachusetts, Rhode Island, Connecticut, and Maryland), despite extensive sampling (Brown et al. 1977; Farley et al. 1986; Brousseau 1987; Farley et al. 1991; Brousseau and Baglivo 1994). The finding of positive cases of gonadal neoplasia in clams from New Brunswick, Nova Scotia, and Prince Edward Island, has extended the known range to the north, but further sampling will be required to more fully delineate the distribution of this disease (Barber et al. 2002).

\subsubsection{Mercenaria spp.}

The hardshell clam, or quahog, Mercenaria spp. is distributed along the east coast of North America. The northern quahog, M. mercenaria, is found along the entire east coast,

\footnotetext{
${ }^{2}$ Representative cases of gonadal neoplasia from this study were assigned accession nos. RTLA 6071, 6072, and 6073) in the Registry of Tumors in Lower Animals (see Peters et al. 1994).
}

while the southern quahog, M. campechiensis, occurs along the southern portion of the Atlantic coast of the USA, and into the Gulf of Mexico. Along the east coast of Florida, these two species occur sympatrically and hybridize extensively (Bert et al. 1993).

The first report of gonadal neoplasia in Mercenaria mercenaria was provided by Yevich and Barry (1969), who histologically examined 1300 clams from Narragansett Bay, Rhode Island, and found three cases of gonadal neoplasia, all of which were females. Subsequent examination of an additional 539 quahogs revealed an additional 14 cases (12 female and 2 male), for an overall prevalence of $2.6 \%$ (Barry and Yevich 1972). Hesselman et al. (1988) examined quahogs, Mercenaria spp. from the Indian River Lagoon, Florida for two years and found gonadal neoplasia at an overall prevalence of $11.6 \%$ (147/1263). Monthly prevalence ranged from $3.3 \%$ to $31.5 \%$, and was greatest between May and September. Affected clams were predominantly female (61\%) and ranged in size from 28.4 to $102 \mathrm{~mm}$ shell height. Bert et al. (1993) determined the genotypes of 1141 quahogs, Mercenaria spp. from the Indian River Lagoon using starch gel electrophoresis, and determined that hybrids had a significantly higher proportion of gonadal neoplasia (21.6\%) compared to either M. mercenaria $(6.5 \%)$ or M. campechiensis $(11.8 \%)$; again, neoplasia occurred more frequently in females than males. Thus, similar to the situation for Mya arenaria, gonadal neoplasia has a relatively small distribution within the overall geographic range of Mercenaria spp.

\subsection{Physiological effects}

Although the disease appears to be progressive based on histological information, the extent to which resultant mortality occurs is unclear. There is, however, little question that affected clams exhibit abnormal gametogenesis and a reduction in fecundity (Eversole and Heffernan 1995; Barber 1996).

\subsubsection{Sublethal effects}

The pathological effects of gonadal neoplasia are reviewed by Peters et al. (1994). The early cases reports by Yevich and Barry (1969) and Barry and Yevich (1972) included invasion to the supporting connective tissue, red gland and genital pores, and the attachment of metastatic cells to the heart muscle. Similar invasion and destruction of connective tissue and adjacent muscles was reported by Hesselman et al. (1988). In extreme cases, neoplastic cells completely replace and destroy normal tissue architecture, making sexual differentiation impossible (Barry and Yevich 1975; Hesselman et al. 1988; Peters et al. 1994; Barber 1996), and undoubtedly resulting in severe physiological dysfunction.

Thus the most obvious sublethal effect of gonadal neoplasia on bivalves is the alteration of normal gametogenic processes. As the disease progresses, undifferentiated germ cells proliferate and replace normal gametes, reducing fecundity in affected individuals. The effect of gonadal neoplasia on female softshell clams, Mya arenaria, was quantified by Barber (1996). He found that clams with neoplasms produced 
significantly fewer oocytes than clams without neoplasms; overall, oocyte numbers were reduced by $66 \%$ as a result of direct displacement by neoplastic cells. In addition, it was found that clams with neoplasms produced (and presumably spawned) significantly smaller ova than clams without neoplasms (Barber 1996). Together these findings have serious reproductive implications for populations (both M. arenaria and Mercenaria spp.) in which the disease is epizootic. First, the total number of ova produced will be reduced and second, the reduced size of ova spawned by diseased individuals may compromise subsequent larval growth and survival, both of which could negatively affect population fitness and sustainability.

Unlike disseminated neoplasia, for which there is little documented relationship between disease occurrence and gender, a significant majority of clams with gonadal neoplasms (both in Mercenaria spp. and M. arenaria) are females, and advanced cases (involving invasion or metastasis) in Mercenaria spp., are exclusively females (Barry and Yevich 1972; Hesselman et al. 1988; Bert et al. 1993; Barber 1996; Barber et al. 2002). One of two possibilities could account for this observation. The first is that females are somehow more susceptible to the development of the disease. Why this would be the case is not obvious. The second possible explanation is that the disease affects sexual differentiation, resulting in neoplastic clams having a higher proportion of females than clams without the disease. Since this disease represents an impairment of normal gametogenic processes, it is not unreasonable to suggest that the disease might result in a disruption of the normal genetic or hormonal control mechanisms associated with sexual differentiation and gamete formation. This is supported by Barber (1996), who noted that the effects of neoplasms were general in nature, affecting the entire gonad (not just the follicles filled with neoplastic cells). A secondary factor might be the timing of disease acquisition relative to sexual maturity. Expression of the disease prior to sexual differentiation might lead to a higher proportion of females than males. Disease expression after sexual differentiation has occurred may alter the sex of the individual, depending on the species and its propensity for protandry.

\subsubsection{Lethal effects}

Based on histological evidence, gonadal neoplasia is progressive and undoubtedly results in the deaths of at least some individuals (see Sect. 3.2). Affected animals cannot be repeatedly sampled non-destructively (as is the case for disseminated neoplasia), making quantification of the rate of disease progression and subsequent mortality difficult. Barber et al. (2002) attempted to determine rates of mortality caused by gonadal neoplasia by placing 50 individually numbered softshell clams, Mya arenaria, into each of 10 replicate $1 \mathrm{~m}^{2}$ predator exclusion cages at a site where gonadal neoplasia is enzootic (18\% prevalence). Mortality was assessed monthly by removing and counting all clams. Cumulative mortality over the six month study period was $3.4 \%$, which is considerably lower than that associated with disseminated neoplasia, and suggests that disease progression is slow and mortality is low but continual. The fact that very few advanced (Stage 3) cases are found suggests that once the disease progresses beyond a certain point, mortality occurs quickly (Barber et al. 2002). Mortality rates associated with gonadal neoplasia in quahogs, Mercenaria spp. have not been determined, but given the pathology of advanced cases of the disease (Hesselman et al. 1988), there is little doubt that at least some mortality occurs.

\subsection{Ontogeny}

The tissue of origin of gonadal neoplasia is clearly germinal epithelium, as first described by Barry and Yevich (1972). This is supported by numerous observations that abnormal cells are initially confined to lumens of gonadal follicles (Hesselman et al. 1988; Peters et al. 1994; Barber 1996).

\subsection{Etiology}

Transmission of gonadal neoplasia in the laboratory, either through proximity experiments or injection of neoplastic cells, has not been documented. Barber et al. (2002) examined the potential for disease transmission in the field, by moving softshell clams, Mya arenaria, from a site in southern Maine where gonadal neoplasia does not occur to a site in eastern Maine where gonadal neoplasia is enzootic (18\% prevalence). Fifty clams from each location were individually numbered and placed into each of 10 replicate $1 \mathrm{~m}^{2}$ predator exclusion cages. At two month intervals over a six month period, 50 clams from each source ( 5 from each cage) were examined histologically. None of the clams from the disease-free site developed cases of gonadal neoplasia after being held in close proximity to diseased clams at a site where the disease is epizootic, indicating that an infective agent is either not involved or takes longer than six months to manifest itself (Barber et al. 2002).

\subsubsection{Viral}

The fact that transmission of gonadal neoplasia has not been successfully demonstrated, as it has for disseminated neoplasia, supports a non-infective etiology. Nonetheless, possible viral involvement in the disease has been suggested. Intranuclear inclusions seen in neoplastic cells of quahogs, Mercenaria mercenaria, resembled those of herpes virus-like inclusions (Farley 1978). Harshbarger et al. (1979) noted the presence of inclusions in the nuclei of germinoma cells in softshell clams, Mya arenaria. Confirmation that these or any other cellular inclusions are viral in nature, has yet to be provided (Harshbarger et al. 1979; Hesselman et al. 1988; Peters et al. 1994).

\subsubsection{Environmental contamination}

It was originally thought that gonadal neoplasms were caused by the carcinogenic effects of specific pollutant events. The first reports of gonadal neoplasms in Mya arenaria came 
from Long Cove, Maine after a spill of No. 2 fuel oil and JP 5 jet fuel occurred in 1971 (Barry and Yevich 1975; Yevich and Barszcz 1976, 1977; Harshbarger et al. 1979). Barry and Yevich (1975) found that the highest prevalence of neoplasms occurred in the area of greatest oil impact. Brown et al. (1977) examined clams from sites throughout New England known to be impacted by various types of pollution, but only found gonadal neoplasms in Long Cove, Maine. Gardner et al. (1991) associated neoplasm occurrence with exposure to herbicides Tordon 101, 2, 4-D, and 2, 4, 5-T, used in blueberry agriculture and forestry in the vicinity of Denny's Bay, Maine; herbicide bioaccumulation levels in clam tissue was not analyzed. Environmental contamination does not seem to be correlated with incidence of gonadal neoplasia in Mercenaria spp. in Florida (Hesselman et al. 1988; Bert et al. 1993).

Very few bioassay experiments evaluating the relationship between exposure to specific chemicals and the development of gonadal neoplasms have been conducted. For example, exposure to petroleum hydrocarbons for 45-360 days resulted in no observable pathological effects (Yevich and Barszcz 1977; Gardner et al. 1991). The lack of a relationship between petroleum hydrocarbons exposure and pathology was used by Gardner et al. (1991) to support their contention of an herbicide etiology (in spite of any supporting chemical analysis). In a more recent short-term exposure study, Van Beneden et al. (1998) looked for potential alterations in the expression of genes possibly associated with increased cell cycling by exposing softshell clams, $M$. arenaria, to 2,3,7,8tetrachlorodibenzo- $p$-dioxin-[1,6- $\left.{ }^{3} \mathrm{H}\right]$ for $24 \mathrm{hr}$. Subsequent examination of RNA from gill and gonadal tissue from exposed clams using differential display polymerase chain reaction identified an E3 ubiquitinating enzyme and an RNA helicase as potentially up-regulated genes, supporting the ability of dioxin to induce cell proliferation (Van Beneden et al. 1998). As pointed out by the authors, these initial indications of differential gene expression need to be confirmed by an independent measure, such as Northern blotting. Thus, given that gonadal neoplasms do not occur in all clam populations exposed to environmental contamination and do occur in some unimpacted locations (e.g., the Indian River Lagoon), together with the fact that attempts to induce the disease have been unsuccessful, it is likely that the etiology of this disease involves factors other than pollution alone.

Even though environmental contaminants probably do not play a direct causative role in the development of gonadal neoplasms, there is the possibility that they may be indirectly involved. Environmental levels of petroleum hydrocarbons and anthropogenic compounds such as DDT, TBT, and PCBs have recently been shown to alter normal reproductive processes in mollusks by disrupting endocrine functions, including the neuropeptides that control sexual differentiation and gametogenesis (Morcillo and Porte 2000; Oberdorster and Cheek 2001). If gonadal neoplasms are influenced by hormonal processes (see Sect. 3.4.1), then environmental contaminants could facilitate development of the disease by disrupting normal hormonally mediated processes. No direct evidence exists, however, suggesting that these mechanisms are involved in neoplasm formation and altered sex ratios in either Mercenaria spp. or Mya arenaria. The fact that gonadal neoplasms do not occur in
M. arenaria populations in more heavily impacted urban areas to the south of Maine make it unlikely that endocrine modulation is involved in the formation of gonadal neoplasms.

\subsubsection{Biotoxin}

Landsberg (1996) examined the possible role of biotoxins as etiological agents of bivalve neoplasms, and noted a positive relationship between the general distributions of germinomas in softshell clams, Mya arenaria and blooms of the toxic dinoflagellate, Alexandrium spp. Biotoxin (saxitoxin) monitoring data from the Maine Department of Marine Resources allows a closer examination of this possible relationship along the coast of Maine, where gonadal neoplasms are epizootic to the north Penobscot Bay but non-existent to the south (see Sect. 3.3.1). The average saxitoxin level detected in tissues of M. arenaria along the entire Maine coast between 1988 and 1997 ranged from 0 to $35 \mu \mathrm{g} / 100 \mathrm{mg}$. Unlike the distribution of neoplasms, however, which occurred only to the north of Penobscot Bay, saxitoxin is accumulated in equal amounts in clam tissues both to the north and south of Penobscot Bay. Thus, when examined on a smaller scale, there is a complete lack of correlation between saxitoxin concentration in clam tissue and the occurrence of gonadal neoplasia and no support for this hypothesis. A similar examination has not been made for populations of quahogs, Mercenaria spp., affected by gonadal neoplasia.

\subsubsection{Other stressors}

The limited distributional range of this disease near the northern geographic limit of Mya arenaria and the southern geographical limit of Mercenaria spp. suggests that temperature may be involved in neoplasm development. How either low or high temperature per se would actually promote gonadal neoplasia is not obvious. The major effect of low temperature on clam populations would be to reduce growth such that for a given size, clams from northern populations would be generally older than those from southern populations. Senescence could result in altered cellular processes such that populations having a higher proportion of older individuals might have a higher prevalence of gonadal neoplasia. To the contrary, however, Barber et al. (2002) found no relationship between clam size and disease prevalence. Generally lower temperatures, however, may account for the low rate of disease progression observed in M. arenaria in Maine (Barber et al. 2002). Hesselman et al. (1988) noted that prevalence of gonadal neoplasia in quahogs, Mercenaria spp., from the Indian River Lagoon is highest in the summer months, when water temperature is the greatest. Prevailing temperatures $\left(>30{ }^{\circ} \mathrm{C}\right)$ are indeed stressful in late summer, as indicated by the fact that gametogenesis in this population is arrested during the months of August and September (Hesselman et al. 1989). A temperature mediated alteration of normal gametogenic processes could lead to an increase in gonadal neoplasia. 


\subsubsection{Genetic}

The Indian River population of quahogs, Mercenaria spp., consists of approximately 68\% M. mercenaria, $4 \%$ M. campechiensis, and $28 \%$ hybrid genotypes (Bert et al. 1993; Arnold et al. 1996). Bert et al. (1993) was the first to recognize that prevalence of gonadal neoplasia differed among the three genotypes, with the hybrids having a significantly higher prevalence $(21.6 \%)$ than either M. mercenaria $(6.5 \%)$ or M. campechiensis $(11.8 \%)$. Similarly, Eversole and Heffernan (1995) produced pure and hybrid lines of quahogs from broodstock of both species and reared them in separate, protected trays in South Carolina. Subsequent histopathological examination revealed that overall prevalence of gonadal neoplasia was $47 \%$. More notably, average monthly prevalence of neoplasia in one hybrid group (M. campechiensis female $\mathrm{x}$ $M$. mercenaria male) was significantly greater $(81.4 \%)$ than either parental line, and, disease severity was also greater in hybrids than purebreds (Eversole and Heffernan 1995). These studies clearly indicate a genetic predisposition for gonadal neoplasia in Mercenaria spp. hybrids. Introgressive hybridization could contribute to an increased prevalence of gonadal neoplasia in two possible ways (Bert et al. 1993). The first involves the potential for the disruption of co-adapted allele combinations of proto-oncogenes and their associated tumorsuppressor genes by both backcrossing and mutation. Second, elevated mutation rates in hybrids could increase the frequency of genetically altered proto-oncogenes that deregulate cell growth. Regardless of the exact mechanism, the finding that hybrids are more likely to develop cases of gonadal neoplasia has potentially serious implications for both sympatric wild populations and hatchery production of Mercenaria spp.

\section{Future directions}

Several major questions regarding both disseminated and gonadal neoplasia remain unanswered. The primary challenge to the research community in the near future will be to address the etiology of both diseases and the ontogeny of disseminated neoplasia. To date, most of what we know about these diseases is based in field investigations. These observations now need to be critically examined in carefully designed and conducted laboratory examinations. One area that has received little attention is the determination of the carcinogenic effects of various environmental contaminants (including both anthropogenic compounds and biotoxins) on marine bivalves and their potential role in inducing neoplasia. Unfortunately, long term exposure studies are often compromised by the difficulty in keeping experimental animals under optimal nutritional conditions for long periods in the laboratory. The key to unlocking these mysteries lies in the development and application of more sophisticated cellular and molecular tools to the study of molluscan diseases, many of which already exist in the human bio-medical field.

Regardless of etiology, the initiation and progression of neoplastic disease results from a breakdown of normal cellular processes. The development of a primary molluscan cell line is critical to many aspects of molluscan biology, including disease. Despite previous attempts, however, no such cell line currently exists. What will be required for the establishment of such lines is a concerted, systematic approach to developing optimal culture media and physical conditions for each cell type (La Peyre et al. 2001). Establishment of such lines could advance the study of neoplasia by providing the ability to examine the regulation of cell division (both promoters and inhibitors). The ability to maintain cell lines is also critical to the study of viruses and their potential role as etiological agents. Continuous cultures of hemocytes would not only provide much information about hematopoiesis and the relationship between granular and hyaline cells but also provide insights into the ontogeny of circulating neoplastic cells associated with disseminated neoplasia.

Investigation into the molecular basis of the initiation of neoplasia in bivalves is beginning to receive some attention. For example, DNA from gonadal tumors of both Mya arenaria and Mercenaria spp. transformed NIH3T3 cells which subsequently induced tumors when injected into mice, thus indicating the presence of a transforming gene in tumor cells (Van Beneden et al. 1993). More recently, Kelley et al. (2001) investigated the expression of homologs for human p53 and p73 genes (responsible for regulation of cell cycling) in M. arenaria and found using Western blot analysis that Map 53 and Map 73 were both expressed in gill, gonad, digestive gland, mantle, adductor muscle, and hemocyte tissues. Map 53 was expressed at higher levels than Map 3 in all tissues. Map 73 had an elevated expression in both adductor muscle and hemocytes of clams having disseminated neoplasia. The authors speculate that the existence of these highly conserved genes in clams may also serve similar functional roles to those in humans (Kelley et al. 2001). Finally, a greater understanding of the development of proliferative disorders in bivalves could provide a model for the study of human cancer.

\section{References}

Alderman D.J., Van Banning P., Perez-Colomer A., 1977, Two European oyster (Ostrea edulis) mortalities associated with an abnormal haemocytic condition. Aquaculture 10, 335-340.

Arnold W.S., Bert T.M., Hesselman D.M., Blake N.J., 1996, Gonadal neoplasia in hard clams (Mercenaria spp.) from the Indian River Lagoon, Florida. J. Shellfish Res. 15, 518.

Auffret M., Poder M., 1986, Sarcomatous lesion in the cockle Cerastoderma edule II. Electron microscopical study. Aquaculture 58, 9-15.

Balouet G., Poder M., 1980, A proposal for classification of normal and neoplastic types of blood cells in molluscs. In: Yohn, Lapin Blakeslee (Eds.), Advances in Comparative Leukemia Research 1979. Elsevier North Holland, Inc., pp. 205-208.

Balouet G., Poder M., Cahour A., Auffret M., 1986, Proliferative hemocytic condition in European flat oysters (Ostrea edulis) from Breton coasts: a 6-year survey. J. Invertebr. Pathol. 48, 208-215.

Barber B.J., 1990, Seasonal prevalence and intensity and disease progression of neoplasia in soft shell clams, Mya arenaria, from the Shrewsbury River, New Jersey. In: Perkins F.O., Cheng T.C. (Eds.), Pathology in Marine Science. Academic Press, Inc., San Diego, pp. 377-386.

Barber B.J., 1995, Seasonal prevalence of gonadal neoplasms in clams, Mya arenaria, in Maine and impact on oogenesis. J. Shellfish Res. 14, 238. 
Barber B.J., 1996, Effects of gonadal neoplasms on oogenesis in softshell clams, Mya arenaria. J. Invertebr. Pathol. 67, 161-168.

Barber B.J., Davis C.V., 1994, Disease studies in Maine-1993. J. Shellfish Res. 13, 311.

Barber B.J., Davis C.V., Crosby M.A., 1998, Cultured oysters, Crassostrea virginica, genetically selected for fast growth in the Damariscotta River, Maine, are resistant to mortality caused by Juvenile Oyster Disease (JOD). J. Shellfish Res. 17, 1171-1175.

Barber B.J., MacCallum G.S., Robinson S.M.C., McGladdery S.E., 2002, Occurrence and lack of transmissibility of gonadal neoplasia in softshell clams, Mya arenaria, in Maine (USA) and Atlantic Canada. Aquat. Living Resour. 15, 319-326.

Barry M., Yevich P.P., 1975, Part III. Histopathological studies. Mar. Pollut. Bull. 6, 171-173.

Barry M.M., Yevich P.P., 1972, Incidence of gonadal cancer in the quahaug. Oncology 26, 87-96.

Bert T.M., Hesselman D.M., Arnold W.S., Moore W.S., Cruz-Lopez H., Marelli D.C., 1993, High frequency of gonadal neoplasia in a hard clam (Mercenaria spp.) hybrid zone. Mar. Biol. 117, 97-104.

Bower S.M., McGladdery S.E., Price I.M., 1994, Synopsis of infectious diseases and parasites of commercially exploited shellfish. Annu. Rev. Fish Dis. 4, 1-199.

Brousseau D.J., 1987, Seasonal aspects of sarcomatous neoplasia in Mya arenaria (soft-shell clam) from Long Island Sound. J. Invertebr. Pathol. 50, 269-276.

Brousseau D.J., Baglivo J.A., 1991a, Field and laboratory comparisons of mortality in normal and neoplastic Mya arenaria. J. Invertebr. Pathol. 57, 59-65.

Brousseau D.J., Baglivo J.A., 1991b, Disease progression and mortality in neoplastic Mya arenaria in the field. Mar. Biol. 110, 249-252.

Brousseau D.J., Baglivo J.A., 1994, Notes on epizootiological aspects (sex and age) of disseminated neoplasia in Mya arenaria from Long Island Sound. J. Invertebr. Pathol. 63, 214-216.

Brown R.S., 1980, The value of the multidisciplinary approach to research on marine pollution effects as evidenced in a three-year study to determine the etiology and pathogenesis of neoplasia in the soft-shell clam, Mya arenaria. J. Conseil 179, 125-128.

Brown R.S., Wolke R.E., Saila S.B., Brown C.W., 1977, Prevalence of neoplasia in 10 New England populations of the soft-shell clam (Mya arenaria). Ann. NY Acad. Sci. 298, 522-534.

Cooper K.R., Brown R.S., Chang P.W., 1982a, The course and mortality of a hematopoietic neoplasm in the soft-shell clam, Mya arenaria. J. Invertebr. Pathol. 39, 149-157.

Cooper K.R., Brown R.S., Chang P.W., 1982b, Accuracy of blood cytological screening techniques for the diagnosis of a possible hematopoeitic neoplasm in the bivalve mollusc, Mya arenaria. J. Invertebr. Pathol. 39, 281-289.

Cosson-Mannevy M.A., Wong C.S., Cretney W.J., 1984, Putative neoplastic disorders in mussels (Mytilus edulis) from southern Vancouver Island waters, British Columbia. J. Invertebr. Pathol. 44, 151-160.

Elston R.A., Kent M.L., Drum A.S., 1988a, Progression, lethality and remission of hemic neoplasia in the bay mussel Mytilus edulis. Dis. Aquat. Org. 4, 135-142.

Elston R.A., Kent M.L., Drum A.S., 1988b, Transmission of hemic neoplasia in the bay mussel, Mytilus edulis, using whole cells and cell homogenate. Dev. Comp. Immunol. 12, 719-727.

Elston R.A., Drum A.S., Allen S.K. Jr., 1990, Progressive development of circulating polyploid cells in Mytilus with hemic neoplasia. Dis. Aquat. Org. 8, 51-59.

Elston R.A., Moore J.D., Brooks K., 1992, Disseminated neoplasia of bivalve molluscs. Rev. Aquat. Sci. 6, 405-466.
Eversole A.G., Heffernan P.B., 1995, Gonadal neoplasia in northern Mercenaria mercenaria (Linnaeus, 1758) and southern M. campechiensis (Gmelin, 1791) quahogs and their hybrids cultured in South Carolina. J. Shellfish Res. 14, 33-39.

Farley C.A., 1969a, Probable neoplastic disease of the hematopoietic system in oysters, Crassostrea virginica and Crassostrea gigas. Nat. Cancer Inst. Monogr. 31, 541-555.

Farley C.A., 1969b, Sarcomatoid proliferative disease in a wild population of blue mussels (Mytilus edulis). J. Natl. Cancer Inst. 43, 509-516.

Farley C.A., 1976, Proliferative disorders in bivalve molluscs. Mar. Fish. Rev. 38, 30-33.

Farley C.A., 1978, Viruses and viruslike lesions in marine mollusks. Mar. Fish. Rev. 40, 18-20.

Farley C.A., 1994, Exogenous viruses as possible initiators of neoplasms in aquatic invertebrates. In: Rosenfield A., Kern F.G., Keller B.J. (Eds.), Invertebrate Neoplasia: Initiation and Promotion Mechanisms. U.S. Department of Commerce, Woods Hole, MA, pp. 26-27.

Farley C.A., Otto S.V., Reinisch C.L., 1986, New occurrence of epizootic sarcoma in Chesapeake Bay soft shell clams, Mya arenaria. Fish. Bull. 84, 851-857.

Farley C.A., Plutschak D.L., Scott R.F., 1991, Epizootiology and distribution of transmissible sarcoma in Maryland softshell clams, Mya arenaria, 1984-1988. Environ. Health Perspect. 90, 35-41.

Ford S.E., Haskin H.H., 1987, Infection and mortality patterns in strains of oysters Crassostrea virginica selected for resistance to the parasite Haplosporidium nelsoni (MSX). J. Parasitol. 73, 368-376.

Ford S.E., Barber R.D., Marks E., 1997, Disseminated neoplasia in juvenile eastern oysters Crassostrea virginica, and its relationship to the reproductive cycle. Dis. Aquat. Org. 28, 73-77.

Frierman E.M., Andrews J.D., 1976, Occurrence of hematopoietic neoplasms in Virginia oysters (Crassostrea virginica). J. Natl. Cancer Inst. 56, 319-322.

Gardner G.R., Yevich P.P., Hurst J., Thayer P., Benyi S., Harshbarger J.C., Pruell R.J., 1991, Germinomas and teratoid siphon anomalies in softshell clams, Mya arenaria, environmentally exposed to herbicides. Environ. Health Perspect. 90, 43-51.

Green M., Alderman D.J., 1983, Neoplasia in Mytilus edulis L. from United Kingdom waters. Aquaculture 30, 1-10.

Harshbarger J.C., Otto S.V., Chang S.C., 1979, Proliferative disorders in Crassostrea virginica and Mya arenaria from the Chesapeake Bay and intranuclear virus-like inclusions in Mya arenaria with germinomas from a Maine oil spill site. Haliotis 8, 243-248.

Hesselman D.M., Blake N.J., Peters E.C., 1988, Gonadal neoplasms in hard shell clams Mercenaria spp., from the Indian River, Florida: Occurrence, prevalence, and histopathology. J. Invertebr. Pathol. 52, 436-446.

Hesselman D.M., Barber B.J., Blake N.J., 1989, The reproductive cycle of adult hard clams, Mercenaria spp. in the Indian River Lagoon, Florida. J. Shellfish Res. 8, 43-49.

Hillman R.E., 1993, Relationship of environmental contaminants to occurrence of neoplasia in Mytilus edulis populations from east and west coast mussel-watch sites. J. Shellfish Res. 12, 109.

House M.L., Kim C.H., Reno P.W., 1998, Soft shell clams Mya arenaria with disseminated neoplasia demonstrate reverse transcriptase activity. Dis. Aquat. Org. 34, 187-192.

Kelley M.L., Winge P., Heaney J.D., Stephens R.E., Farell J.H., Van Beneden R.J., Reinisch C.L., Lesser M.P., Walker C.L., 2001, Expression of homologues for p53 and p73 in the softshell clam (Mya arenaria), a naturally-occurring model for human cancer. Oncogene 20, 748-758. 
Kent M.L., Elston R.A., Wilkinson M.T., Drum A.S., 1989, Impaired defense mechanisms in bay mussels, Mytilus edulis, with hemic neoplasia. J. Invertebr. Pathol. 53, 378-386.

Kent M.L., Wilkinson M.T., Drum A.S., Elston R.A., 1991, Failure of transmission of hemic neoplasia of bay mussels, Mytilus trossulus, to other bivalve species. J. Invertebr. Pathol. 57, 435-436.

Koehn R.K., 1991, The genetics and taxonomy of the species in the genus Mytilus. Aquaculture 94, 125-145.

Krishnakumar P.K., Casillas E., Snider R.G., Kagley A.N., Varanasi U., 1999, Environmental contaminants and the prevalence of hemic neoplasia (leukemia) in the common mussel (Mytilus edulis complex) from Puget Sound, Washington, USA J. Invertebr. Pathol. 73, 135-146.

La Peyre J., Li Y., Buchanan J., Cheng P., Cooper R., Tiersch T., 2001, A systematic approach to develop an oyster cell line. J. Shellfish Res. 20, 546-547.

Landsberg J.H., 1996, Neoplasia and biotoxins in bivalves: is there a connection? J. Shellfish Res. 15, 203-230.

Leavitt D.F., McDowell Capuzzo J., Smolowitz R.M., Miosky D.L., Lancaster B.A., 1990, Hematopoietic neoplasia in Mya arenaria: prevalence and indices of physiological condition. Mar. Biol. 105, 313-321.

Leavitt D.F., Miosky Dragos D., Lancaster B.A., Craig A.C., Reinisch C.L., Capuzzo J.M., 1994, Initiation and promotion of hematopoietic neoplasia in softshells, Mya arenaria, exposed to natural sediment. In: Rosenfield A., Kern F.G., Keller B.J. (Eds.), Invertebrate Neoplasia: Initiation and Promotion Mechanisms. U.S. Department of Commerce, Woods Hole, MA, pp. 23-25.

Lowe D.M., Moore M.N., 1978, Cytological and quantitative cytochemistry of a proliferative atypical hemocytic condition in Mytilus edulis (Bivalvia, Mollusca). J. Natl. Cancer Inst. 60, 1455-1459.

McGladdery S.E., Reinisch C.L., MacCallum G.S., Stephens R.E., Walker C.L., Davidson J.T., 2001, Haemic neoplasia in soft-shell clams (Mya arenaria): Recent outbreaks in Atlantic Canada and discovery of a p53 gene homologue associated with the condition. Bull. Aquac. Assoc. Can. 101-3, 19-26.

McLaughlin S.M., 1994, Transmission studies of sarcoma in the softshell, Mya arenaria. In: Rosenfield A., Kern F.G., Keller B.J. (Eds.), Invertebrate Neoplasia: Initiation and Promotion Mechanisms. U.S. Department of Commerce, Woods Hole, MA, pp. 21-22.

Medina D.J., Paquette G.E., Sadasiv E.C., Chang P.W., 1993, Isolation of infectious particles having reverse transcriptase activity and producing hematopoietic neoplasia in Mya arenaria. $\mathrm{J}$. Shellfish Res. 12, 112-113.

Miosky D.L., Smolowitz R.M., Reinisch C.L., 1989, Leukemia cell specific protein of the bivalve mollusc Mya arenaria. J. Invertebr. Pathol. 53, 32-40.

Mix M.C., 1975, Proliferative characteristics of atypical cells in native oysters (Ostrea lurida) from Yaquina Bay, Oregon. J. Invertebr. Pathol. 26, 289-298.

Mix M.C., 1983, Haemic neoplasms of bay mussels, Mytilus edulis L., from Oregon: occurrence, prevalence, seasonality and histopathological progression. J. Fish Dis. 6, 239-248.

Mix M.C., 1986, Cancerous diseases in aquatic animals and their association with environmental pollutants: A critical literature review. Mar. Environ. Res. 20, 1-141.

Mix M.C., Hawkes J.W., Sparks A.K., 1979, Observations on the ultrastructure of large cells associated with putative neoplastic disorders of mussels, Mytilus edulis, from Yaquina Bay, Oregon. J. Invertebr. Pathol. 34, 41-56.
Moore J.D., Elston R.A., 1993, Pathogenesis of disseminated neoplasia in eastern Pacific Mytilus trossulus. J. Shellfish Res. 12, 136.

Moore J.D., Elston R.A., Drum A.S., Wilkinson M.T., 1991, Alternate pathogenesis of systemic neoplasia in the bivalve mollusc Mytilus. J. Invertebr. Pathol. 58, 231-243.

Morcillo Y., Porte C., 2000, Evidence of endocrine disruption in clams-Ruditapes decussata-transplanted to a tributyltin-polluted environment. Environ. Pollut. 107, 47-52.

Morrison C.M., Moore A.R., Marryatt V.M., Scarratt D.J., 1993, Disseminated sarcomas of soft-shell clams, Mya arenaria Linnaeus 1758, from sites in Nova Scotia and New Brunswick. J. Shellfish Res. 12, 65-69.

Noel D., Boulo V., Chagot D., Mialhe E., Paolucci F., Clavies C., Hervaud E., Elston R.A., 1991, Preparation and characterization of monoclonal antibodies against neoplastic hemocytes of Mytilus edulis (Bivalvia). Dis. Aquat. Org. 10, 51-58.

Oberdorster E., Cheek O., 2001, Gender benders at the beach: Encocrine disruption in marine and estuarine organisms. Environ. Toxicol. Chem. 20, 23-36.

Oprandy J.J., Chang P.W., 1983, 5-Bromodeoxyuridine induction of hematopoietic neoplasia and retrovirus activation in the soft-shell clam, Mya arenaria. J. Invertebr. Pathol. 42, 196-206.

Oprandy J.J., Chang P.W., Pronovost A.D., Cooper K.R., Brown C.W., Yates V.J., 1981, Isolation of a viral agent causing hematopoietic neoplasia in the soft-shell clam, Mya arenaria. J. Invertebr. Pathol. 38, 45-51.

Pauley G.B., 1969, A critical review of neoplasias and tumor-like lesions in mollusks. Nat. Cancer Inst. Monogr. 31, 509-529.

Peters E.C., 1988, Recent investigations on the disseminated sarcomas of marine bivalve molluscs. Am. Fish. Soc. Spec. Publ. 18, 74-92.

Peters E.C., Yevich P.P., Harshbarger J.C., Zaroogian G.E., 1994, Comparative histology of gonadal neoplasms in marine bivalve molluscs. Dis. Aquat. Org. 20, 59-76.

Poder M., Auffret M., 1986, Sarcomatous lesion in the cockle Cerastoderma edule I. Morphology and population survey in Brittany, France. Aquaculture 58, 1-8.

Potts M.-S., 1993, Effects of Hematopoietic Neoplasia on Physiological Processes in the Soft-shell Clam, Mya arenaria (Linne.). Ph.D. Dissertation, University of New Hampshire, pp. 150.

Rasmussen L.P.D., 1986, Occurrence, prevalence and seasonality of neoplasia in the marine mussel Mytilus edulis from three sites in Denmark. Mar. Biol. 92, 59-64.

Reinisch C.L., Charles A.M., Stone A.M., 1984, Epizootic neoplasia in soft shell clams collected from New Bedford Harbor. Hazard. Waste 1, 73-81.

Reno P.W., House M., Illingworth A., 1994, Flow cytometric and chromosome analysis of softshell clams, Mya arenaria, with disseminated neoplasia. J. Invertebr. Pathol. 64, 163-172.

Sindermann C.J., 1990, Principal Diseases of Marine Fish and Shellfish. Academic Press, Inc., San Diego.

Smolowitz R.M., Leavitt D.F., 1996, Neoplasia and other pollution associated lesions in Mya arenaria from Boston Harbor. J. Shellfish Res. 15, 520.

Smolowitz R.M., Reinisch C.L., 1986, Indirect peroxidase staining using monoclonal antibodies specific for Mya arenaria neoplastic cells. J. Invertebr. Pathol. 48, 139-145.

Smolowitz R.M., Miosky D., Reinisch C.L., 1989, Ontogeny of leukemic cells of the soft shell clam. J. Invertebr. Pathol. 53, 41-51.

Sparks A.K., 1985, Synopsis of Invertebrate Pathology Exclusive of Insects. Elsevier, Amsterdam. 
Sunila I., 1991, Respiration of sarcoma cells from the soft-shell clam Mya arenaria L. under various conditions. J. Exp. Mar. Biol. Ecol. 150, 19-29.

Sunila I., 1992, Serum-cell interactions in transmission of sarcoma in the soft shell clam, Mya arenaria L. Comp. Biochem. Physiol. A $102,727-730$.

Sunila I., 1994, Viral transmission and tumor promotion of sarcoma in the softshell, Mya arenaria. In: Rosenfield A., Kern F.G., Keller B.J. (Eds.), Invertebrate Neoplasia: Initiation and Promotion Mechanisms. U.S. Department of Commerce, Woods Hole, MA, pp. 11-13.

Sunila I., Dungan C.F., 1992, Different proteins in the hemolymph sera from sarcomatous and healthy soft shell clams, Mya arenaria L. Comp. Biochem. Physiol. B 102, 621-625.

Twomey E., 1994, Distribution of sarcoma in the cockle, Cerastoderma edule, around the Irish Coast, 1982-91: Implications for pollution etiology. In: Rosenfield A., Kern F.G., Keller B.J. (Eds.), Invertebrate Neoplasia: Initiation and Promotion Mechanisms. U.S. Department of Commerce, Woods Hole, MA, pp. 3-5.

Twomey E., Mulcahy M.F., 1988a, Epizootiological aspects of a sarcoma in the cockle Cerastoderma edule. Dis. Aquat. Org. 5, 225-238.

Twomey E., Mulcahy M.F., 1988b, Transmission of a sarcoma in the cockle Cerastoderma edule (Bivalvia; Mollusca) using cell transplants. Dev. Comp. Immunol. 12, 195-200.
Van Beneden R.J., Rhodes L.D., Gardner G.R., 1998, Studies of the molecular basis of gonadal tumors in the marine bivalve, Mya arenaria. Mar. Environ. Res. 46, 209-213.

Van Beneden R.J., Gardner G.R., Blake N.J., Blair D.G., 1993, Implications for the presence of transforming genes in gonadal tumors in two bivalve mollusk species. Cancer Res. 53, 2976-2979.

Villalba A., Carballal M.J., Lopez C., 2001, Disseminated neoplasia and large foci indicating heavy haemocytic infiltration in cockles Cerastoderma edule from Galicia (NW Spain). Dis. Aquat. Org. 46, 213-216.

Weinberg J.R., Leavitt D.F., Lancaster B.A., McDowell Capuzzo J., 1997, Experimental field studies with Mya arenaria (Bivalvia) on the induction and effect of hematopoietic neoplasia. J. Invertebr. Pathol. 69, 183-194.

White M.K., Miosky D., Flessas D.A., Reinisch C.L., 1993, The expression of an adhesion-related protein by clam hemocytes. J. Invertebr. Pathol. 61, 253-259.

Yevich P.P., Barry M.M., 1969, Ovarian tumors in the quahog Mercenaria mercenaria. J. Invertebr. Pathol. 14, 266-267.

Yevich P.P., Barszcz C.A., 1976, Gonadal and hematopoietic neoplasms in Mya arenaria. Mar. Fish. Rev. 38, 42-42.

Yevich P.P., Barszcz C.A., 1977, Neoplasia in soft-shell clams (Mya arenaria) collected from oil-impacted sites. Ann. NY Acad. Sci. 298, 409-426. 